\title{
Sahaya Özel Zemin Davranış Analizlerinde Profil Derinliği Değişiminin İncelenmesi
}

\author{
Fatma Illknur Kara ${ }^{1 *} \oplus$, Barış Şahin²® \\ ${ }^{1}$ Gebze Teknik Üniversitesi, Mimarlık Fakültesi, Mimarlık Bölümü, 41400, Kocaeli. \\ ${ }^{2}$ AES Dizayn Mühendislik \& Danışmanlık, Suadiye, Kitapçı Sokak, No 14/1/1, 34740, Kadıköy, İstanbul.
}

\section{Özet}

Güncellenerek “Türkiye Bina Deprem Yönetmeliği (TBDY-2018)” ismi ile yürürlüğe giren Türk deprem yönetmeliği, tasarım gözetimi ve kontrolü hizmetinden deprem haritasının güncellenmesine kadar birçok köklü değişiklik içermekte ve uygulamaya yeni koşullar getirmektedir. Getirilen en önemli koşullardan bir tanesi "ZF" yerel zemin sinıfi için "Sahaya Özel Zemin Davranışı Analizi" yapılması gerekliliğidir. Bu çalışmada, yönetmeliğin 16.5.2.3 (a) maddesinde serbest zemin modeli oluşturulması için belirtilen ve özellikle büyük açıklıkl yapı projelerinde pratik olarak uygulaması zor olan ve ek maliyet gerektiren "mühendislik taban kayasının bina temelinden itibaren derinliği, en büyük bina genișliğinin üç katından daha az olmayacaktır” koșulu irdelenmiștir. Bu kapsamda, İzmir ili, Konak ilçesi sınırlarında, zemin değerlendirilmesi yapılmış, bölgenin karakteristik zemin türünü temsil eden "ZF" zemin sınıfina ait bir zemin profili, dört farklı derinlik için oluş̧urulmuştur. Dört farklı deprem düzeyi için ayrı ayrı olmak üzere tasarım spektrumuna spektral uyuşum sağlanacak şekilde dönüştürülen 11 adet deprem kaydının iki yönlü zaman tanım alanında doğrusal olmayan analiz yöntemi ile analizleri tamamlanmış ve farklı derinliklerinin profil davranışına etkileri incelenmiştir. Analizler sonucunda, çalışma kapsamında dikkate alınan zemin profili için yüksek yapı sınıfina girmeyen ve ileri performans hedefi değerlendirmesi gerektirmeyen yeni yapılacak önüretimli betonarme, yerinde dökme betonarme ve çelik binalar için ZE zemin sinıfi için oluşturulan spektrumun derinlik değişiminden bağımsız olarak davranışı karşıladığı belirlenmiştir.

\section{An Investigation of Soil Profile Depth Change on Site Response Analysis}

\begin{abstract}
The updated Turkish seismic code "Building Earthquake Regulations-2018 (TBDY-2018)" includes radical changes in many aspects such as peer review and the earthquake hazard map hence, it brings new conditions into practical engineering. One of the most important conditions is the concept of "Site Response Analysis" for the soil type "ZF". This study investigates the item 16.5.2.3 (a) which states that "the depth of the engineering bedrock from the building foundation must not be less than three times of the largest building width. However, the application of this provision is almost difficult especially for the large span structures, and it requires additional cost. In this context, the soil profile evaluation has been made within the borders of Konak district of İmir province for soil class "ZF" considering four different depths. Non-linear bidirectional time history analyses are performed using 11 pairs of earthquake records which are scaled to match various earthquake levels. The study also evaluates the effect of various depths on the behavior of the soil profile in question. The paper concludes that, for the soil profile addressed in this study, the derived design spectrum related to soil type ZE-regardless of the depth change - is conservative for all periods except the high rise buildings as well as the buildings that do not require advanced performance evaluations such as new designed reinforced concrete buildings, precast concrete buildings and steel buildings.
\end{abstract}

Keywords

TBDY-2018, ZF Soil Type, Site Response Analysis, Nonlinear Analysis

\section{Giriş}

Aktif bir deprem kuşağında bulunan Türkiye nüfusunun \%98'i deprem tehlikesi altında yaşamını sürdürmektedir. Ülkemizde deprem zararlarının azaltılmasına yönelik çalışmalar çok yakın aralıklarla meydana gelen, çok büyük can ve mal kaybına sebep olan Erzincan (27.12.1939), Niksar-Erbaa (20.12.1942), Adapazarı-Hendek (20.06.1943), TosyaLadik (26.11.943) ve (Bolu-Gerede) 01.02.1944 depremlerinden sonra başlamıştır (Özmen 2012). Türkiye'de ilk resmi deprem yönetmeliği 1940 yılında yürürlüğe girmiştir. Toplumsal gereksinimler, deprem mühendisliğindeki gelişmeler ve teknolojik devrimler neticesinde deprem yönetmeliği 1947, 1953, 1961, 1968, 1975, 1998, 2007 ve 2018 yıllarında olmak üzere 8 kez revize edilmiştir. 
Türk Bina Deprem Yönetmeliği (TBDY-2018) (TBDY 2018) olarak adlandırılan son güncel yönetmelik Resmî Gazete'de 18 Mart 2018 tarihinde yayınlanmış, yürürlüğe ise 1 Ocak 2019 tarihinde girmiştir. Türkiye için ilk deprem bölgeleri haritası Sieberg (1932) tarafından hazırlanmış ancak bu harita resmi olarak onaylanmamıştır (Özmen 2012). İlk resmi deprem bölgeleri haritası ise 1945 yılında "Yersarsıntısı Bölgeleri Haritası" ismi ile yayımlanmış ve sonrasında sismotektonik veriler ve deprem mühendisliği alanındaki gelişmelere bağlı olarak 1947, 1963, 1972, 1996 yıllarında güncellenmiştir (Özmen ve Pampal 2017). 1996 yılında yürürlüğe giren Türkiye Deprem Bölgeleri Haritası, AFAD Deprem Dairesi Başkanlığı tarafından yenilenmiş ve Türkiye Deprem Tehlike Haritası (TDTH-2018) ismi ile Türkiye Bina Deprem Yönetmeliği ile eş zamanlı olarak 1 Ocak 2019 tarihinde yürürlüğe girmiştir (TDTH 2019). Yeni haritada, bir önceki haritadan farklı olarak, güncellenen diri fay haritası (Emre vd. 2013) kullanılmış ve "deprem bölgesi” kavramı ortadan kaldırılmıştır. Böylece artık deprem tehlikesi bölge bazında değil her bir lokasyon için ayrı ayrı tanımlanabilmektedir (İMO 2018).

Güncellenen deprem yönetmeliğinde, Deprem Bölgelerinde Yapılacak Binalar Hakkında Yönetmeliğin (DBYBHY 2007) bölümlerinin bir kısmı kapsamlı revizyona uğramış ve yeni bölümler eklenmiştir. Yeni yönetmelikte yapılan en önemli revizyonlardan bir tanesi ilk kez 1975 yönetmeliğinde dikkate alınan ancak sonrasında revize edilmemiş deprem etkisi altında "temel zemini" hakkında ayrıntılı kurallar getirilmiş olmasıdır.

Bu çalışmada ilk olarak TBDY-2018 kapsamında sahaya özel araştırma ve değerlendirme gerektiren zemin türleri ve yönetmelikte bu tür zeminler için getirilen kurallar sunulmuştur. Daha sonra karakteristikleri zemin analizleri sonucu elde edilmiş ve profil boyunca 200 280 m/sn kayma dalgası hızına sahip zemin profili bir boyutlu oluşturulmuş yönetmelikte tanımlanan dört deprem düzeyi için sahaya özel zemin davranış analizleri gerçekleştirilmiştir. Bu çalışmada profil derinliğinin analiz sonuçlarına etkisini inceleyebilmek için zemin profili 30, 50, 70 ve 90 m olacak şekilde 4 farklı derinlik için oluşturulmuştur.

\section{TBDY-2018 Deprem Yer Hareketi ve Yerel Zemin Sınıfları}

Güncellenen yeni deprem yönetmeliğinde deprem yer hareketi konusu, yönetmeliğin 2. bölümünde ayrıntılı şekilde ele alınmıştır. TBDY-2018 yönetmeliğinde standart ivme spektrumunun analitik ifadesi değiştirilmiş, spektrumu oluşturan zemin parametrelerinde ve güncellenen Türkiye Deprem Tehlikesi Haritası ile tanımı değişen "deprem tehlikesi" kavramlarında önemli değişikliklere yer verilmiştir (IMO 2018). Güncellenen yönetmelikte deprem etkisini tanımlayan tasarım ivme spektrumu artık tasarım spektral ivme katsayıları, $\mathrm{S}_{\mathrm{DS}}$ ve $\mathrm{S}_{\mathrm{D} 1}$, değerleri ile oluşturulmaktadır (Şekil 1).

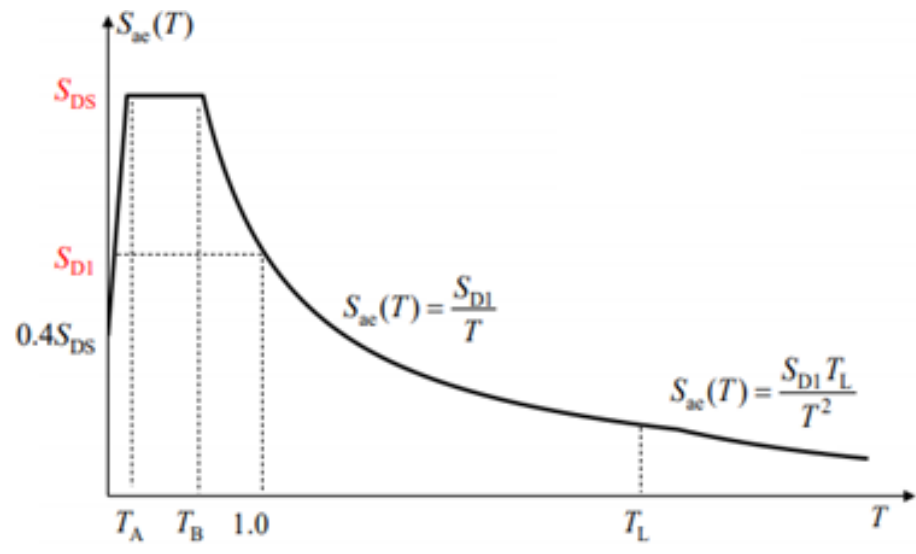

Şekil 1: TBDY-2018 tasarım ivme spektrumu (TBDY 2018)

Şekil 1'de belirtilen $\mathrm{S}_{\mathrm{DS}}$, kısa periyot tasarım spektral ivme katsayısını, $\mathrm{S}_{\mathrm{D} 1}$ ise 1.0 saniye periyot için tasarım spektral ivme katsayısını ifade etmektedir. Bu katsayılar \%5 sönüm oranı için Türkiye Deprem Tehlike Haritaları İnteraktif Web Uygulaması (TDTH-2018) (TDTH 2019) web sitesinden alınan harita spektral ivme katsayıları $\mathrm{S}_{\mathrm{S}}$ ve $\mathrm{S}_{1}$ 'in TBDY-2018 Madde 2.3.3'de verilen yerel zemin etki katsayıları ile çarpımından (Denklem 1) elde edilmektedir (TBDY-2018 Madde 2.3.2.2).

$S_{D S}=S_{S} F_{S}$

$S_{D 1}=S_{1} F_{1}$

Ss kısa periyot harita spektral ivme katsayısı, $\mathrm{S}_{1}$ ise 1.0 saniye periyot için harita spektral ivme katsayısı olarak tanımlanmaktadır. Ss ve $S_{1}$ spektral ivme katsayıları TDTH-2018 web sitesinden, TBDY-2018 Bölüm 2.2'de tanımlanan DD-1, DD-2, DD-3 ve DD-4 deprem düzeyleri için ayrı ayrı elde edilmektedir. Bu deprem düzeylerinin deprem yer hareketi spektral büyüklüklerin 50 yılda aşılma olasılıkları sırasılla, \%2, \%10, \%50 ve \%68 ve tekrarlama periyotları gene sirasıly 2475, 475, 72 ve 43 yıl olarak verilmiştir. 
DD-1 deprem düzeyi çok seyrek deprem yer hareketini nitelemektedir. DD-2 deprem yer hareketi ise standart tasarım deprem yer hareketi olarak adlandırılmaktadır. DD-3 deprem yer hareketi sık deprem yer hareketini nitelemekte ve son olarak DD-4 deprem yer hareketi, servis deprem yer hareketi olarak da adlandırılmaktadır. Deprem yer hareketi düzeyleri, TBDY-2018'de deprem etkisi altında bina performans hedeflerinin tanımlanmasında kullanılmaktadır.

Yerel zemin etki katsayıları $\mathrm{F}_{\mathrm{S}}$ ve $\mathrm{F}_{1}$, TBDY-2018 Tablo 16.1'de tanımlanan yerel zemin sınıflarına bağlı olarak yönetmelikte Tablo 2.1 ve Tablo 2.2'de verilmiştir. Güncellenen yeni deprem yönetmeliğinde verilen yerel zemin sınıfları bu çalışmada Tablo 1'de sunulmuştur. Bu tabloya göre zemin sınıfları üst 30 metrede ortalama kayma dalgası hızlarına göre ZA, ZB, ZC, ZD, ZE ve ZF olarak ayrılmıştır.

TBDY-2018, ZF sınıfı zeminler için sahaya özel davranış analizlerinin yapılması ve sahaya özel deprem yer hareketi spektrumunun kullanılmasını zorunlu hale getirmektedir. Sahaya özel zemin davranış analizleri, yerel zemin koşullarının zemin yüzeyindeki etkisini (örneğin, sismik kayma dalgalarının amplifikasyonu, frekans içeriği üzerindeki etkisi ve yer hareketi süresi) belirlemeyi amaçlamaktadır. Bu yöntemle ilk olarak deprem yer hareketleri mühendislik taban kayasında tanımlanmaktadır. Proje sahasının zemin koşullarına uygun olarak zemin tabakaları modellenmekte ve tanımlanan deprem yer hareketinin profil boyunca değişimi ve zemin yüzeyindeki deprem yer hareketi elde edilmektedir. Lokal zemin özelliklerine bağlı olarak zemin yüzeyindeki spektrumun tahmin edilebilmesi yeni yapılacak binaların tasarımı ve mevcut yapıların performanslarının değerlendirilmesi açısından büyük önem taşımaktadır (Chandler vd. 2002; Tsang vd. 2006), (Ceren ve Karakan 2020). Bu nedenle zemin davranış analizleri deprem mühendisliğinin en güçlü araçlarından biridir. Yakın geçmişte Türkiye'de meydana gelen 17 Ağustos 1999 Kocaeli, 1 Mayıs 2003 Bingöl, 23 Ekim 2011 Van (Özşahin ve Eroğlu 2018) ve 30 Ekim 2020 Ege Denizi (URL-1 2021) depremlerinde lokal zemin özelliklerinin dikkate alınmaması sebebiyle büyük can ve mal kayıpları meydana gelmiştir. Ülkemizde zemin davranışı ve zemin büyütmesi üzerine lokal ölçekte yapılmış çalışmalar mevcuttur. Kuzey Anadolu Fay hattında meydana gelebilecek olası bir depremin Bursa il merkezinde yapabileceği etkiyi araştırmak için il merkezinin kuzey-doğu kesiminin sıvılaşma, zemin büyütmesi ve oturma potansiyelleri incelenmiştir (Başarı 2011). Kırıkkale İlinin dinamik zemin davranış özellikleri (Sönmezer vd. 2015) tarafından çalışılmıştır. Deprem sonrası zeminin en üst tabakasındaki pik ivmeleri ve elastik spektrumları elde edebilmek için (Bayrakcı ve Baran 2018) tarafından Osmaniye il merkezi için kentte meydana gelen en büyük deprem kayıtları da kullanılarak zemin davranış analizleri gerçekleştirilmiştir. Kahramanmaraş İlinin dinamik davranış özelliklerinin belirlenmesi için zemin davranış analizleri (Ceren ve Karakan 2020) tarafından çalışılmıştır.

Tablo 1: Yerel zemin sınıfı tablosu (TBDY 2018)

\begin{tabular}{|c|c|c|c|c|}
\hline \multirow{2}{*}{$\begin{array}{l}\text { Yerel } \\
\text { Zemin } \\
\text { Sinıfı }\end{array}$} & \multirow[b]{2}{*}{ Zemin Cinsi } & \multicolumn{3}{|c|}{ Üst 30 metrede ortalama } \\
\hline & & $\begin{array}{l}\left(\mathbf{V}_{\mathrm{s}}\right)_{30} \\
{[\mathrm{~m} / \mathrm{s}]}\end{array}$ & $\begin{array}{c}\left(N_{60}\right)_{30} \\
{[\text { darbe/30cm] }}\end{array}$ & $\begin{array}{l}\left(c_{\mathrm{u}}\right)_{30} \\
{[\mathrm{kPa}]}\end{array}$ \\
\hline $\mathrm{ZA}$ & Sağlam, sert kayalar & $>1500$ & - & - \\
\hline ZB & Az ayrışmış, orta sağlam kayalar & $760-1500$ & - & - \\
\hline $\mathrm{ZC}$ & $\begin{array}{l}\text { Çok sıkı kum, çakıl ve sert kil tabakaları veya } \\
\text { ayrışmış, çok çatlaklı zayıf kayalar }\end{array}$ & $360-760$ & $>50$ & $>250$ \\
\hline ZD & $\begin{array}{l}\text { Orta sıkı - sıkı kum, çakıl veya çok katlı kil } \\
\text { tabakaları }\end{array}$ & $180-360$ & $15-50$ & $70-250$ \\
\hline $\mathrm{ZE}$ & $\begin{array}{l}\text { Gevşek kum, çakıl veya yumuşak - katı kil } \\
\text { tabakaları veya } \\
P I>20 \text { ve } w>\% 40 \text { koşullarını sağlayan } \\
\text { toplamda } 3 \text { metreden daha kalın yumuşak kil } \\
\text { tabakası }\left(c_{\mathrm{u}}<25 \mathrm{kPa}\right) \text { içeren profiller }\end{array}$ & $<180$ & $<15$ & $<70$ \\
\hline $\mathrm{ZF}$ & \multicolumn{4}{|c|}{$\begin{array}{l}\text { Sahaya özel araştırma ve değerlendirme gerektiren zeminler: } \\
\text { 1) Deprem etkisi altında çökme ve potansiyel göçme riskine sahip zeminler (sıvılaşabilir } \\
\text { zeminler, yüksek derecede hassas killer, göçebilir zayıf çimentolu zeminler vb.), } \\
\text { 2) Toplam kalınlığı } 3 \text { metreden fazla turba ve/veya organik içeriği yüksek killer, } \\
\text { 3) Toplam kalınlığı } 8 \text { metreden fazla olan yüksek plastisiteli }(P I>50) \text { killer, } \\
\text { 4) Çok kalın (> } 35 \text { m) yumuşak veya orta katı killer. }\end{array}$} \\
\hline
\end{tabular}

TBDY-2018, Madde 16.5.2.2'e göre zemin davranış analizleri zaman tanım alanında doğrusal olmayan analiz veya eşdeğer doğrusal hesap modeli kullanılarak ardışı yaklaşımla doğrusal olmayan analiz yöntemleri ile gerçekleştirilebilmektedir. Analizlerde kullanılan zemin modeli, bina temeli ve yakın çevresinin zemin ortamının yaklaşık olarak yatay tabakalardan oluştuğu durumlarda tek boyutlu yatay tabakalı serbest zemin modeli olarak aksi durumda ise iki veya üç boyutlu zemin modeli olarak oluşturulacaktır. Serbest zemin modeli, arazi ve laboratuvar deney sonuçlarından elde edilen kayma modülleri ve eşdeğer histeretik sönüm katsayılarının doğrusal olmayan değişimleri dikkate alınarak oluşturulmalıdır. TBDY-2018 Madde 16.5.2.3 (a) göre mühendislik taban kayasının bina temelinden itibaren derinliğinin, en büyük bina genişliğinin üç katından ve kazıklı sistemlerde en uzun kazık boyundan daha az olmaması ve Tablo 16.1'e göre yerel zemin sınıfının ZA veya ZB olacak şekilde alınması gerekmektedir. 
Ancak, taban kayasının yukarıda verilen alt sınıra oranla çok daha derinlerde olması durumunda yönetmelik zemin tabakasının yerel zemin sınıfi ZC veya ZD ile sonlandirılmasına izin vermektedir (Madde 16.5.2.3 (b)). Bu durumda deprem etkisi, taban kayası yerine zemin etki katsayıları göz önüne alınarak büyütülen bu tabakanın üstünde tanımlanabilmektedir.

Zemin modelinin taban kayasına göre elde edilen elastik ivme spektrumu ile uyuşumlu en az on bir deprem kaydının TBDY-2018 Madde 2.5.3'e göre tanımlanması gerekmektedir. Tanımlanan deprem kayıtları ile tamamlanan zemin davranış analizleri sonucunda elde edilen zemin yüzeyi spektral ivme değerlerinin taban kayası spektral ivme değerlerine oranı ve bu oranların en az on bir kayıt için ortalaması alınarak, ilgili periyot için "yerel zemin etki katsayısı" değerleri elde edilecektir. Sahaya özel deprem spektrumu, yerel zemin etki katsayılarının taban kayası için tanımlanan spektrum ile çarpılmasıyla elde edilecektir.

\section{Sahaya Özel Zemin Davranış Analizlerinin Uygulanması}

Deprem etkisi altında zeminlerin ve yapıların davranışını doğru belirleyebilmek için, analizlerde kullanılacak zemin ortamının ve deprem yer hareketinin doğru tanımlanabilmesi gerekmektedir (Kilıçer ve Özgan 2018). Bu çalışmada sahaya özel zemin davranış analizleri;

1. Zemin özelliklerinin belirlenip, zemin profilinin oluşturulması,

2. Deprem yer hareketi kayıtlarının seçilmesi ve spektral uyuşum sağlayacak şekilde dönüştürülmesi

3. Zemin davranış analizlerinin yapılması ve sonuçları olarak üç ana başlık altında toplanmıştır.

\subsection{Zemin Profilinin Oluşturulması}

Sahaya özel zemin davranış analizleri için İzmir ili, Konak ilçe sınırlarında olan bir alan seçilmiştir. Zemin davranış analizlerinde kullanılacak zemin profilleri geoteknik, jeolojik ve jeofiziksel araştırmalar ve zemin numuneleri üzerinde yapılan laboratuvar deneylerine bağlı olarak oluşturulmaktadır. Bu çalışmada, zemin temel etüt çalışmaları kapsamında 8 adet sondaj kuyusunda standart penetrasyon testleri (SPT), jeofizik çalışmalar kapsamında ise sismik kırılma ve çok kanallı yüzey dalgalarının analizi (MASW) çalışmaları yapılan gerçek bir zemin profili üzerine çalışmalar yapılmıştır. Alana ait sismik, MASW, remi ve mikrotremör ölçümü sonuçlarına göre $90 \mathrm{~m}$ derinlik için zemin kayma dalgası hızı elde edilmiştir. Zemin profillinin kayma dalgası hızı profil boyunca 200 280 m/sn aralığında değişmektedir. İlk $10 \mathrm{~m}$ ve 80 90 m derinlikler için MASW ölçümlerinin sonuçları SPT-N değerleri ile literatürde olan araştırmalara dayalı olarak doğrulanmıştır. Kullanılan yöntemler (Imai 1977; Lee 1990) ve karşılaştırma sonuçları Tablo 2'de sunulmuştur.

Tablo 2: SPT-N değerleri ile MASW ölçümlerinin sonuçlarının doğrulanması

\begin{tabular}{|c|c|c|c|}
\hline & & $\begin{array}{c}0-10 \mathrm{~m} \\
\text { SPT-N }=7, V_{\mathrm{s}}=200 \mathrm{~m} / \mathrm{sn}\end{array}$ & $\begin{array}{c}80-90 \mathrm{~m} \\
\text { SPT-N }=20, V_{\mathrm{s}}=258 \mathrm{~m} / \mathrm{sn}\end{array}$ \\
\hline (Imai 1977) & $\mathrm{V}_{\mathrm{s}}=102 * \mathrm{~N} 0,292$ & $180.03 \mathrm{~m} / \mathrm{sn}$ & $244.62 \mathrm{~m} / \mathrm{sn}$ \\
\hline (Lee 1990) & $\mathrm{V}_{\mathrm{s}}=114.43 * \mathrm{~N} 0,31$ & $209.18 \mathrm{~m} / \mathrm{sn}$ & $289.64 \mathrm{~m} / \mathrm{sn}$ \\
\hline
\end{tabular}

Sismik ölçüm çalışmaları, TBDY-2018 Madde 16.5.2.3 (b) uyarınca 90 m derinlikte yaklaşık 260 m/sn kayma dalgası hızı değeri ile tamamlanmış ve zemin profili ZD zemin tabakası ile sonlandırılmıştır. 1999 yılında İzmir Büyükşehir Belediyesi RADIUS projesi (URL-2 1999) ve USGS Vs,30 (USGS 2020) harita sistemi verilerine göre Konak, Bayraklı, Çiğli ilçelerinin kayma dalga hızları ZD (180 360 m/sn) aralığında değişmektedir ve bölgenin genel zemin profili çalışma kapsamında oluşturulan profil ile temsil edilebilmektedir (Şekil 2).

Yapılan arazi çalışmalarına göre proje sahasının kumlu siltli yüksek plastisiteli çok yumuşak-yumuşak kil $(\mathrm{CH})$ birimi olduğu belirlenmiştir. Ayrıca incelenen çalışma sahasının zemin sıvılaşma riskinin olmadığı ancak SPT-N değerlerinin düşük olması nedeniyle deprem anında yumuşama riski olduğu belirlenmiştir. TBDY-2018 Tablo 16.1'e göre, toplam kalınlığg 8 metreden fazla olan yüksek plastisiteli (PI $>50)$ killer ve çok kalın ( $>35$ m) yumuşak veya orta katı kil zeminler ZF zemin sınıfı olarak tanımlanmakta ve sahaya özel zemin davranış analizi yapılması gerekliliği doğmaktadır. Ayrıca profil içinde kum bantları bulunmaktadır. Proje sahasında 90m kadar yapılan sondaj verilerinden yararlanılarak 4 farklı derinlik için, 30m, $50 \mathrm{~m}, 70 \mathrm{~m}, 90 \mathrm{~m}$ tek boyutlu zemin profilleri oluşturulmuştur. Oluşturulan bu farklı derinlikteki zemin profillerinin doğal frekans ve doğal periyot değerleri Tablo3'de belirtilmiştir. Zemin profillerinin oluşturulması ve sahaya özel zemin davranış analizlerinin yapılması için DeepSoil v7 (Hashash vd. 2020) yazılımı kullanılmıştır. Zemin profilleri oluşturulurken dinamik kayma modülünün derinlikle değişimini temsil eden kayma dalgası hızı (Vs) ve kayma modülü, plastisite indeksi, sönüm oranı dikkate alınmıştır. 
Tablo 3: Zemin profillerinin doğal periyot ve doğal frekans değerleri

\begin{tabular}{|c|c|c|}
\hline Profil Derinliği (m) & Doğal Periyot (sn) & Doğal Frekans (Hz) \\
\hline 30 & 0.551 & 1.816 \\
\hline 50 & 0.858 & 1.166 \\
\hline 70 & 1.153 & 0.867 \\
\hline 90 & 1.461 & 0.685 \\
\hline
\end{tabular}

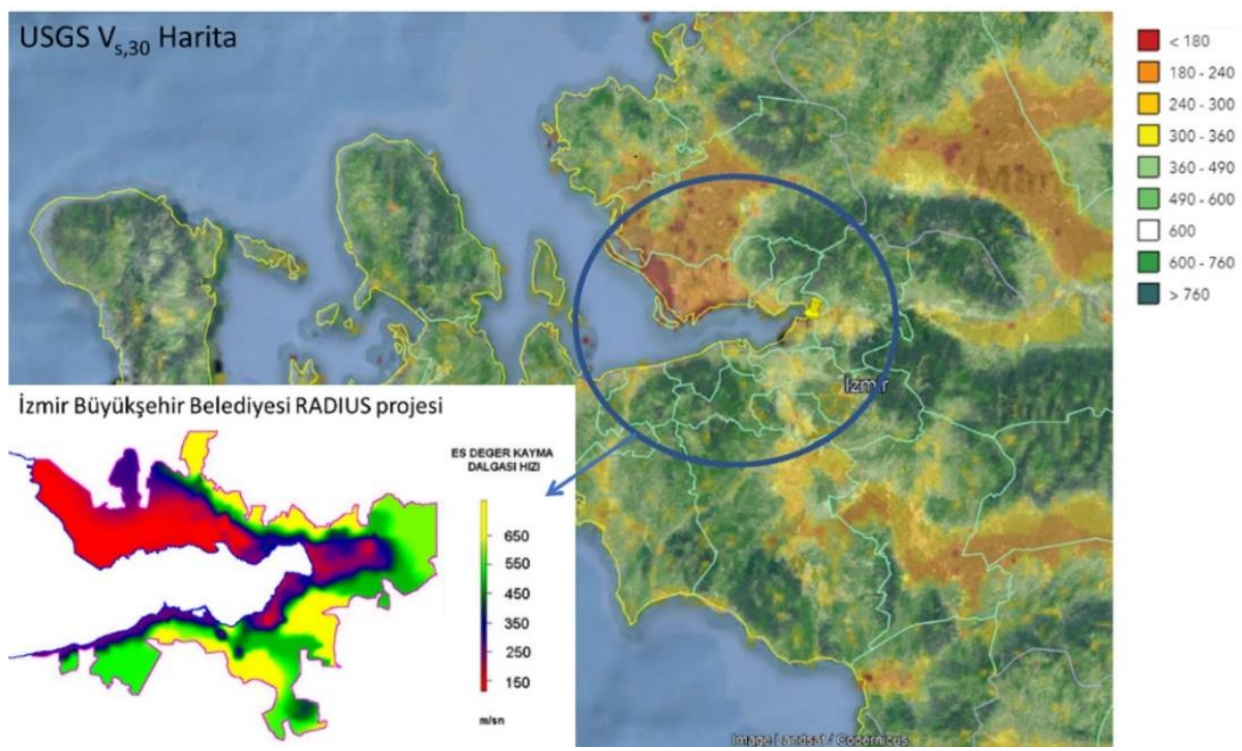

Şekil 2: IBB RADIUS projesi ve USGS Vs,30 haritasına göre Izmir Ili kayma dalgası hızı haritası

Zemin profilleri analizin hassasiyeti bakımından $1.0 \mathrm{~m}$ kalınlığında olan alt tabakalardan oluşturulmuştur. Zemin profillerini temsil etmesi bakımından $90 \mathrm{~m}$ derinlik için oluşturulun zemin profili Şekil 3'te verilmiştir. Deformasyona bağlı kayma modülü azalım ve sönüm eğrileri Deepsoil yazılımının içerisinde gömülü bulunan eğrilerden seçilmiştir. Kil tabakası için (Vucetic ve Dobry1991), kum tabaka için (Seed ve Idriss 1970) kullanılmıştır. Çalışmada kullanılan zemin profilinin özellikleri Tablo 4, sönüm ve kayma modülü eğrileri Şekil 4 ile verilmiştir.

Tablo 4: Zemin profilinin özellikleri

\begin{tabular}{|c|c|c|c|c|}
\hline Derinlik (m) & İsim & $\begin{array}{c}\text { Birim hacim ağırlığı } \\
\left(\mathrm{kN} / \mathrm{m}^{3}\right)\end{array}$ & Vs (m/sn) & $\begin{array}{c}\text { PI } \\
\text { Plastisite indeksi }\end{array}$ \\
\hline 8.5 & $\mathrm{CH}$ & 17.84 & 143 & 25 \\
\hline 9.5 & $\mathrm{CH}$ & 17.8 & 260 & 26 \\
\hline 10.5 & $\mathrm{CH}$ & 17.84 & 260 & 27 \\
\hline 15.5 & $\mathrm{CH}$ & 18.14 & 299 & 31 \\
\hline 18.5 & GC & 18.14 & 228 & 28 \\
\hline 19.5 & GC & 18.14 & 228 & 10 \\
\hline 20.5 & GP & 18.14 & 296 & 30 \\
\hline 25.5 & $\mathrm{CH}$ & 18.14 & 296 & 30 \\
\hline 30.5 & GP & 18.14 & 299 & 28 \\
\hline 40.5 & $\mathrm{CH}$ & 17.75 & 330 & 27 \\
\hline 50.5 & $\mathrm{CH}$ & 18.33 & 343 & 33 \\
\hline 70.5 & $\mathrm{CH}$ & 18.33 & 350 & 33 \\
\hline 80.5 & $\mathrm{CH}$ & 18.33 & 345 & 33 \\
\hline 90.5 & $\mathrm{CH}$ & 18.33 & 335 & 33 \\
\hline \multicolumn{5}{|c|}{$\begin{array}{l}\text { CH (Kumlu siltli yüksek plastiseli çok yumuşak-yumuşak kil) } \\
\text { GC (Kumlu siltli killi orta sıkı çakıl) } \\
\text { GP (Kötü derecelendirilmiş siltli kumlu orta sıkı çakı1) }\end{array}$} \\
\hline
\end{tabular}




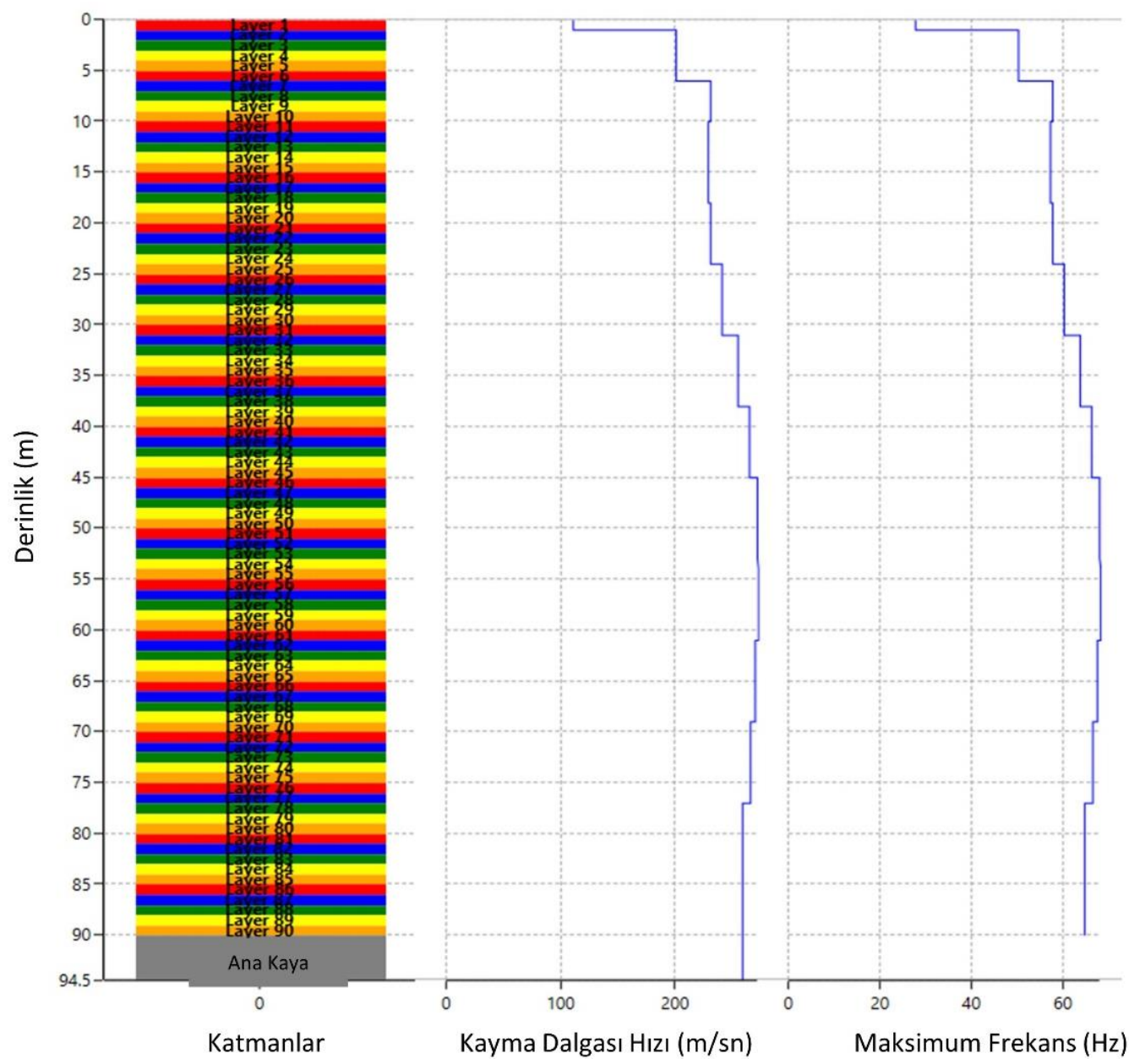

Şekil 3: Zemin profili (90 m)

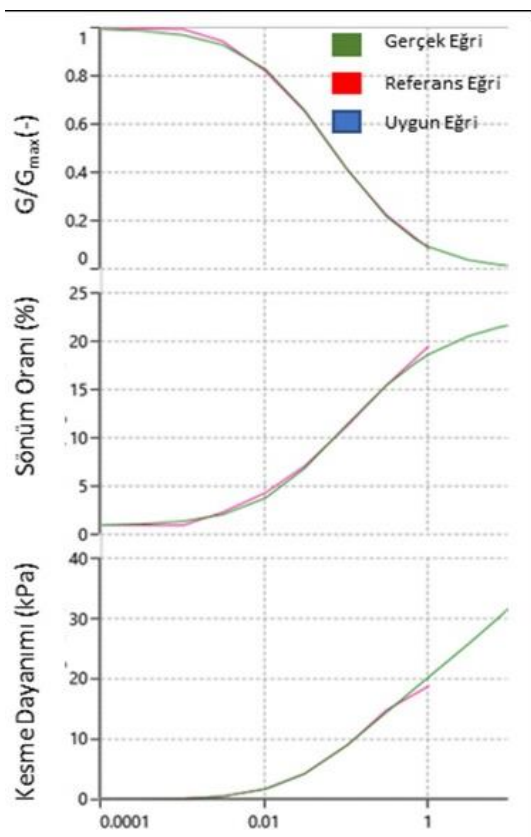

Kayma Birim Şekildeğiştirmesi

(a) En üst tabaka (Kil)
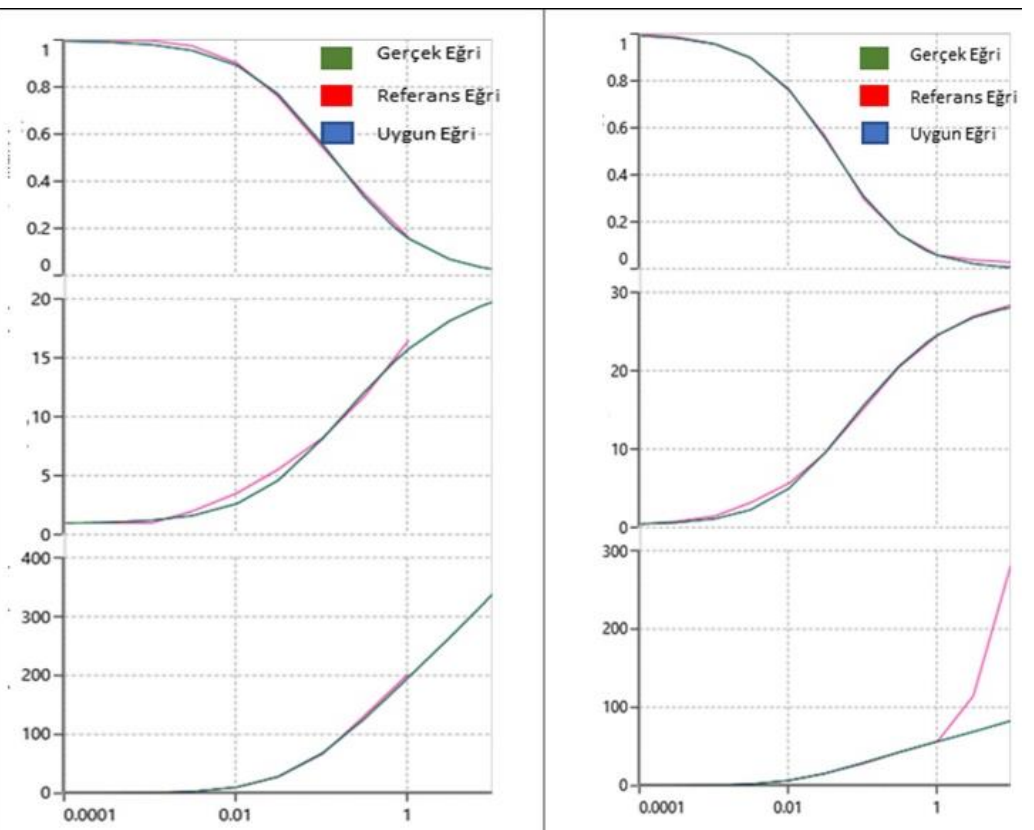

Kayma Birim Şekildeğiştirmesi

(b) En alt tabaka (Kil)
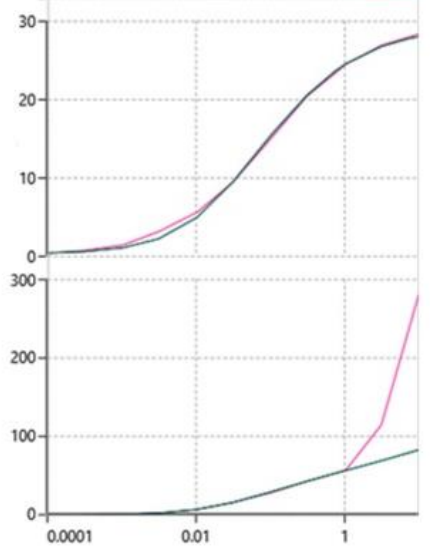

(c) Kum bantları
Kayma Birim Şekildeğiştirmesi

Şekil 4: Analizlerde kullanılan sönüm ve kayma modülü eğrileri 


\subsection{Bölgenin Depremselliği ve Deprem Tehlikesinin Belirlenmesi}

Bir bölgenin deprem tehlikesinin belirlenip değerlendirilmesi için, bölgenin zemin sınıfı ve koşulları, yerel jeolojisi, bölgeyi etkileyecek fayların mekanizmaları ve ayrıca özellikleri, bölgenin güncel deprem aktivitesi ve bölgeyi geçmişte etkilemiş olan tarihsel deprem kayıtlarının araştırılması gerekmektedir.

İzmir ve çevresi, Bornova Karmaşığı olarak adlandırılan, büyük deformasyona uğramış bir filiş matriks ve içinde yüzen mafik volkanit, serpantinit, radyolarit ve mesozoyik yaşlı kireçtaşı bloklarından oluşan bir formasyon ile yüzeylenmiştir. Bölgesel temel, Neojen yaşlı gölsel tortullar ile örtülmüştür. Temel birim üzerine uyumsuz olarak gelen bu tortullar üstten alta doğru killi kireçtaşı, marn, kiltaşı, silttaşı, kumtaşı, çakıltaşı birimlerinden oluşmaktadır (Çağlar vd. 2020).

İzmir ve çevresinde tarihsel dönemlerden itibaren oldukça yoğun deprem aktivitesi gözlemlenmiştir. M.Ö. 1800-M.S. 1900 tarihleri arasında şiddeti $\mathrm{I}_{\mathrm{o}}=\mathrm{IX}-\mathrm{X}$ olan depremler büyük kayıplara sebep olmuştur. Büyük kayıplara sebep olan bu depremlerin şiddetleri ve yılları Şekil 5 ile sunulmaktadır (URL-3 2021). Akdeniz-Himalaya Kuşağı'nda yer alan bölgede 1900-2021 yılları arasında büyüklüğü 5.0-8.0 arasında değișen 574 adet deprem meydana gelmiştir (Şekil 6)(URL-4 2021).

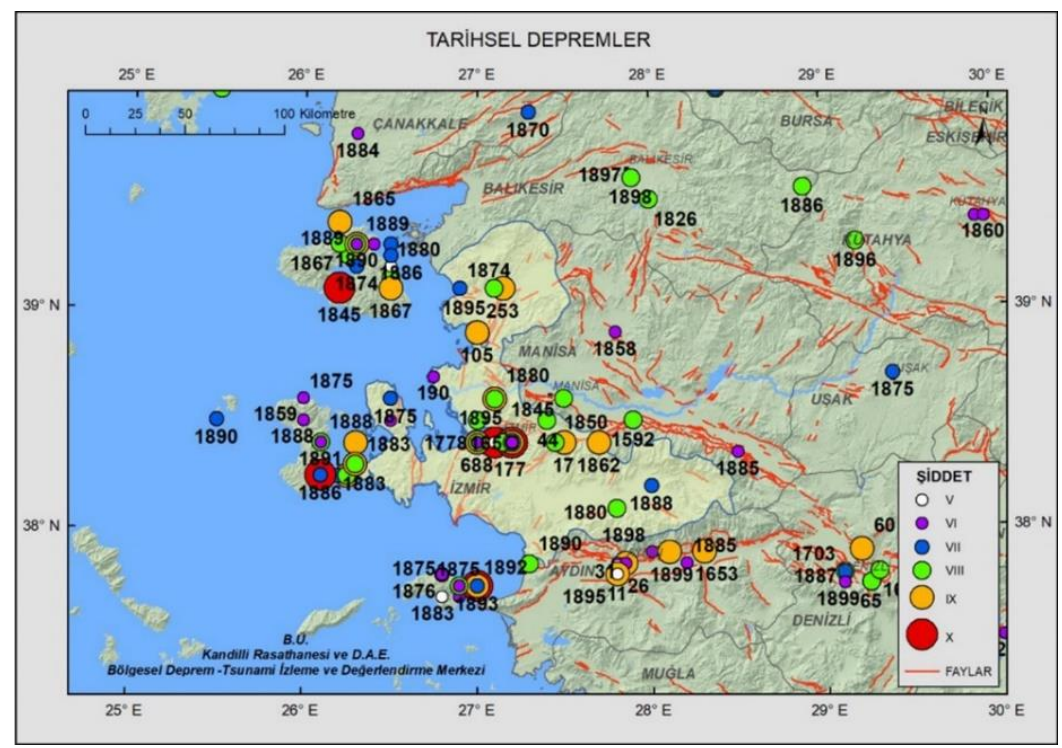

Şekil 5: İmir ili ve yakın çevresinde tarihsel dönemde şiddeti $I_{0}=I X-X$ olan depremler

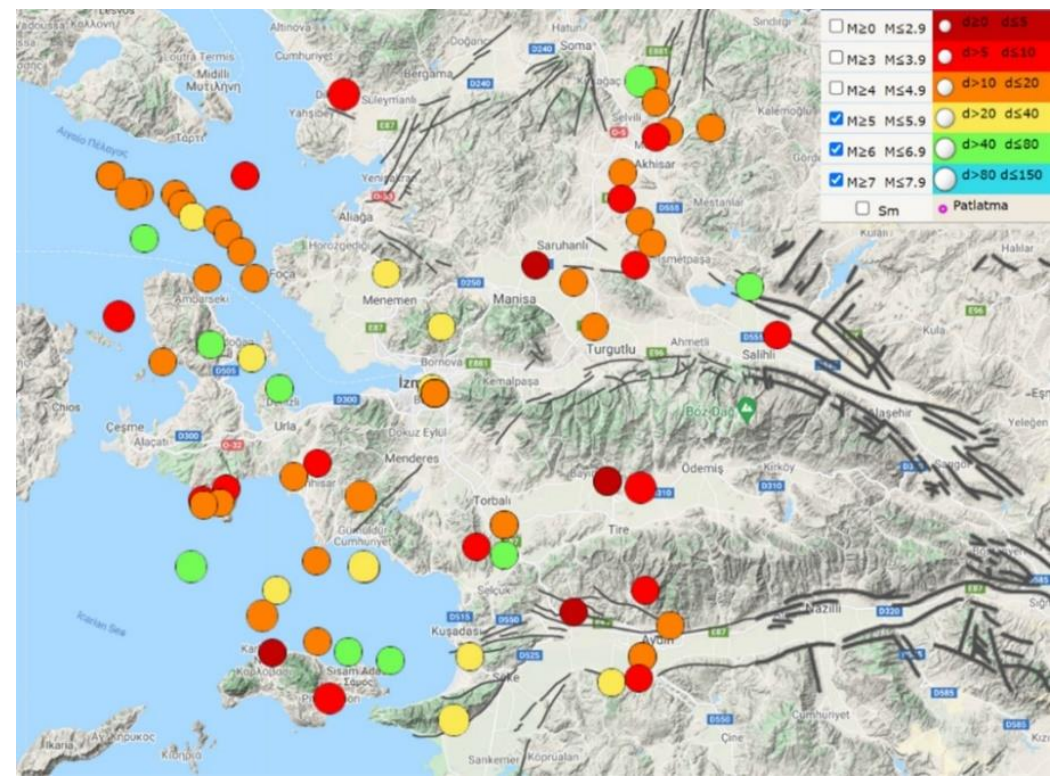

Şekil 6: Izmir ili ve yakın çevresi son 300 yılda meydana gelmiş depremler 
İzmir ve yakın çevresi Gediz graben sisteminin batı ucunda yer almaktadır. Bu sistem Batı Anadolu açılmalı tektonik rejimi içerisinde gelişmiş en büyük yapılardan biridir. Gediz grabeni dışında kalan bölgelerin faylanması, bu fayların aktivitesi ve niteliği hakkında yeterince bilgi mevcut değildir. İzmir kenti merkez olmak üzere yaklaşık $50 \mathrm{~km}$ yarıçapındaki bir alanda diri fay haritalaması gerçekleştirildiği çalışmalarda (Emre vd. 2005) fayların KD-GB, K-G, KBGD ve D-B doğrultularında uzanmakta olduğu belirlenmiştir. Bu faylardan D-B uzanımlı olanları normal fay, diğer uzanımlardaki faylar ise ağırlıklı olarak doğrultu atımlıdır. İzmir ve çevresindeki diri fayların dağılımı ve niteliklerini belirlemek için şehir merkezinden itibaren $100 \mathrm{~km}$ çapındaki bir alanda diri fay haritalaması çalışmaları gerçekleştirilmiştir. Bu çalışmalar neticesinde Gediz grabeni batısında kalan bölgede kompleks bir deformasyon olduğunu gösterir. Bölgedeki faylar ve fayların mekanizmaları Şekil 7 ile sunulmaktadır.

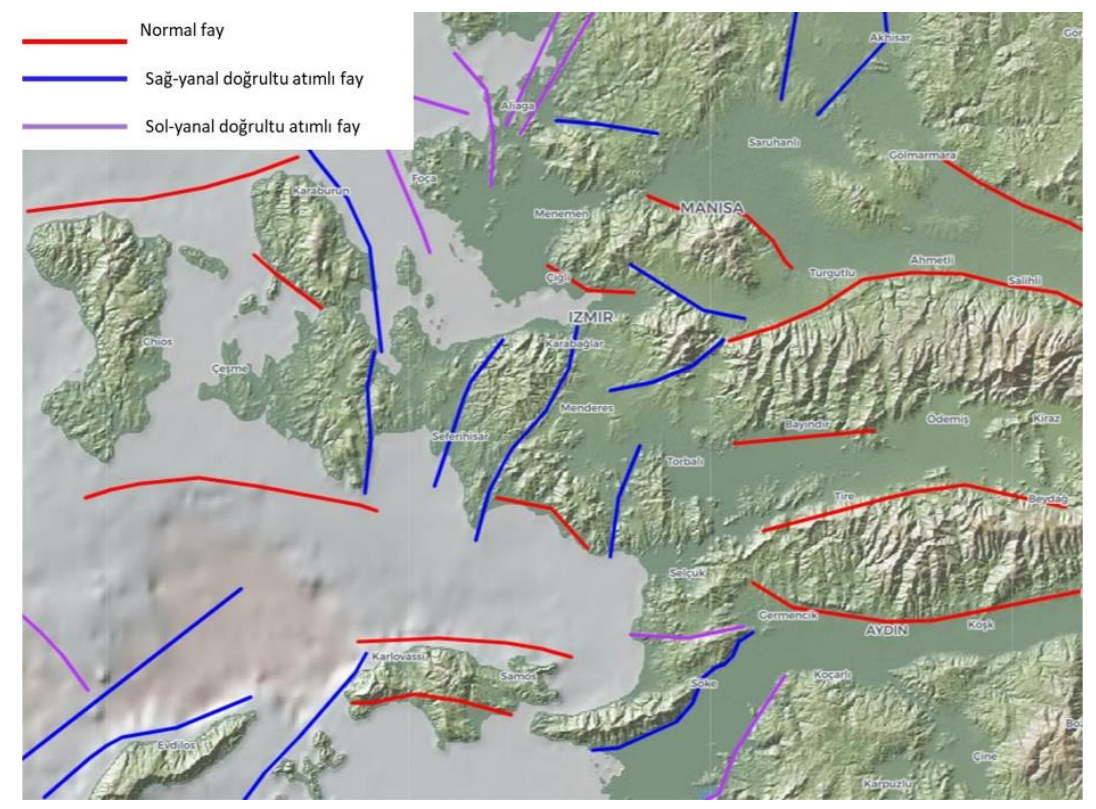

Şekil 7: Bölgedeki faylar ve fayların mekanizmaları

\subsection{Deprem Yer Hareketi Kayıtlarının Seçilmesi ve Spektral Uyuşum Sağlayacak Şekilde Dönüştürülmesi}

TBDY-2018, zaman tanım alanında yapılacak analizler için en az 11 adet deprem yer hareketi takımının (yatay doğrultuda birbirine dik iki yatay bileşen için ivme kayıtları) seçilmesini şart koşmaktadır. Ayrıca aynı depremden seçilecek kayıt veya kayıt takımı sayısının üçü geçmemesi gerekmektedir. Deprem etkisi altında zeminlerin ve yapıların davranışını doğru belirleyebilmek için zemin profilinin ve deprem yer hareketinin doğru tanımlanabilmesi gerekmektedir (Kılıçer ve Özgan 2018). Deprem kayıtları, ilgili deprem yer hareketi düzeyi ile uyumlu yerel zemin koşulları, deprem büyüklüğü, fay uzaklığı, kaynak mekanizması gibi parametreler dikkate alınarak seçilecektir.

TBDY-2018 Madde 16.5.2'ye veya 16.10'a göre yapılacak zemin davranış analizlerinde kullanılacak deprem yer hareketleri, seçilen deprem yer hareketleri kayıtlarının yönetmelikte tanımlanan tasarım spektrumuna spektral uyuşum sağlanacak şekilde dönüştürülmesi ile elde edilebilir. Ayrıca TBDY-2018 Madde 2.5.3'e göre dönüştürülen deprem yer hareketlerinin spektrumlarının ortalamaları, tüm periyotlar için tasarım spektrumu ordinatlarından daha küçük olmaması gerekmektedir.

Bu çalışmada analizlerde kullanılmak üzere yönetmelikte tanımlanan dört deprem düzeyi için bölge depremselliği ile uyumlu gerçek deprem ivme kayıtları seçilmiştir. Proje sahası için Türkiye Deprem Tehlike Haritaları İnteraktif Web Uygulaması (TDTH-2018) (TDTH 2019) web sitesinden elde edilen Yatay Tasarım Spektrum İvme Değerleri Tablo 6 ile sunulmuştur.

Deprem yer hareketleri, PEER NGA Veri Bankası (PEER Center 2013) (4096 adet yer hareketi) kullanılarak seçilmiştir. Deprem moment büyüklüğü, MW=6.53-7.2 aralığında ve zemin kayma dalgası hızı 202-361 m/s aralığında değişen deprem yer hareketleri seçilmiş ve Tablo 5 ile sunulmuştur. 
Tablo 5: Seçilen deprem yer hareketleri ve karakteristik özellikleri

\begin{tabular}{|c|c|c|c|c|c|}
\hline $\begin{array}{c}\text { Deprem } \\
\text { Yıl }\end{array}$ & $(\mathbf{M w})$ & Fay Mekanizma & İstasyon & $\begin{array}{c}\text { En Yakın Mesafe } \\
(\mathbf{k m})\end{array}$ & $\begin{array}{c}\mathbf{V}_{\mathbf{s 3 0}} \\
(\mathbf{m} / \mathbf{s n})\end{array}$ \\
\hline $\begin{array}{c}\text { Imperial Valley-06 } \\
1979\end{array}$ & 6.53 & Doğrultu atımlı & El Centro Differential Array & 5.09 & 202.26 \\
\hline $\begin{array}{c}\text { Imperial Valley-06 } \\
1979\end{array}$ & 6.53 & Doğrultu atımlı & Holtville Post Office & 7.5 & 202.89 \\
\hline $\begin{array}{c}\text { Corinth_Greece } \\
1981\end{array}$ & 6.6 & Normal verev atımlı & Corinth & 10.27 & 361.4 \\
\hline $\begin{array}{c}\text { Chalfant Valley-02 } \\
1986\end{array}$ & 6.19 & Doğrultu atımlı & Bishop - LADWP South St & 17.17 & 303.47 \\
\hline $\begin{array}{c}\text { Superstition Hills-02 } \\
1987\end{array}$ & 6.54 & Doğrultu atımlı & Westmorland Fire Sta & 13.03 & 193.67 \\
\hline $\begin{array}{c}\text { Loma Prieta } \\
1989\end{array}$ & 6.93 & Ters verev atımlı & Gilroy Array \#3 & 12.82 & 349.85 \\
\hline $\begin{array}{c}\text { Kobe_Japan } \\
1995\end{array}$ & 6.9 & Doğrultu atımlı & Shin-Osaka & 19.15 & 256 \\
\hline $\begin{array}{c}\text { Kobe_Japan } \\
1995\end{array}$ & 6.9 & Doğrultu atımlı & Takarazuka & 0.27 & 312 \\
\hline $\begin{array}{c}\text { El Mayor-Cucapah_Mexico } \\
2010\end{array}$ & 7.2 & Doğrultu atımlı & Meloland_E Holton Rd. & 30.63 & 196 \\
\hline $\begin{array}{c}\text { Darfield_New Zealand } \\
\text { 2010 }\end{array}$ & 7 & Doğrultu atımlı & DSLC & 8.46 & 295.74 \\
\hline $\begin{array}{c}\text { Darfield_New Zealand } \\
\text { 2010 }\end{array}$ & 7 & Doğrultu atımlı & Kaiapoi North School & 30.53 & 255 \\
\hline
\end{tabular}

Seçilen deprem kayıtlarının proje sahası için elde edilen dört deprem düzeyi spektrumları ile uyumlu 11 adet 2 yönlü deprem yer hareketlerinin faya normal ve faya paralel bileşenleri için spektral ivme ve spektral deplasman değerleri sırasıyla Şekil 8,9,10 ve 11 ile verilmiş ve dört deprem düzeyinde de dönüştürülen deprem yer hareketlerinin spektrumlarıın ortalamalarının, tüm periyotlar için tasarım spektrumu ordinatlarından daha küçük olmadığı gösterilmiştir.
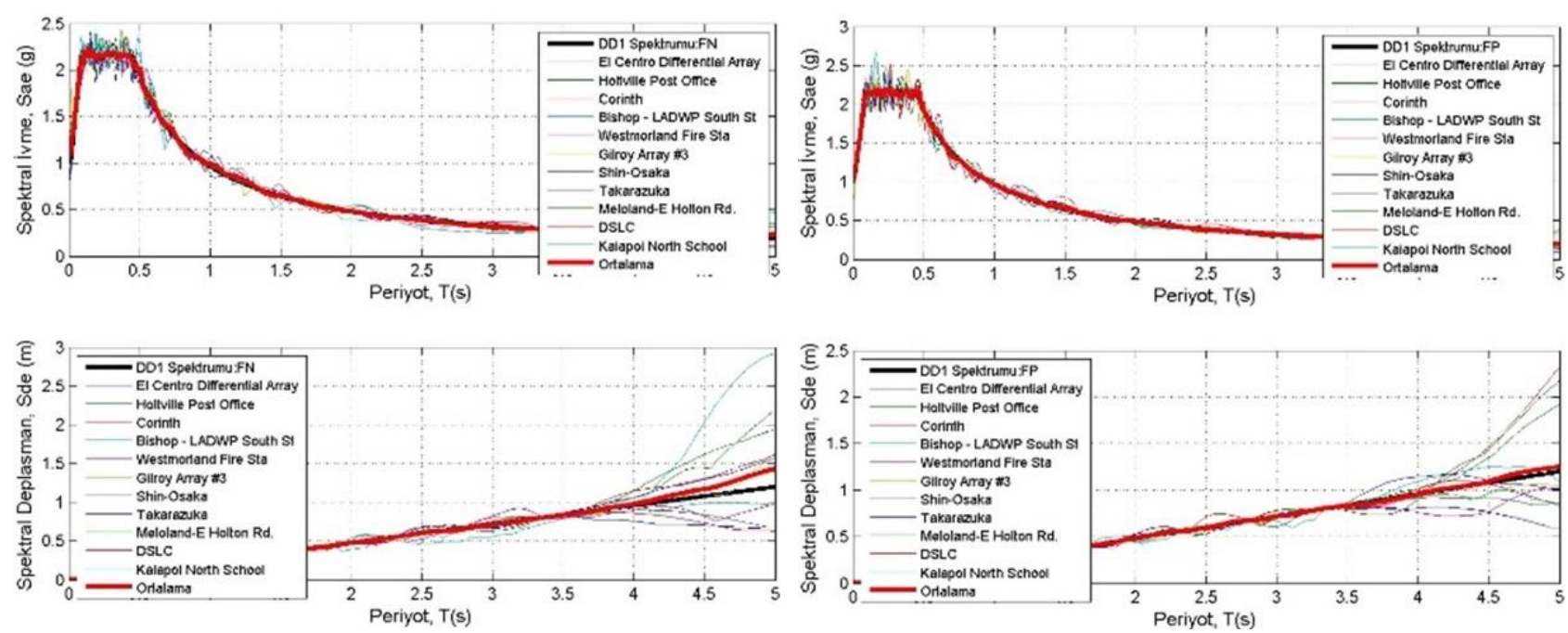

Şekil 8: DD-1 Spektrumu ile uyumlu 11 adet 2 yönlü deprem yer hareketlerinin a) faya normal b) faya paralel doğrultuları için spektral ivme ve spektral deplasman değerleri 

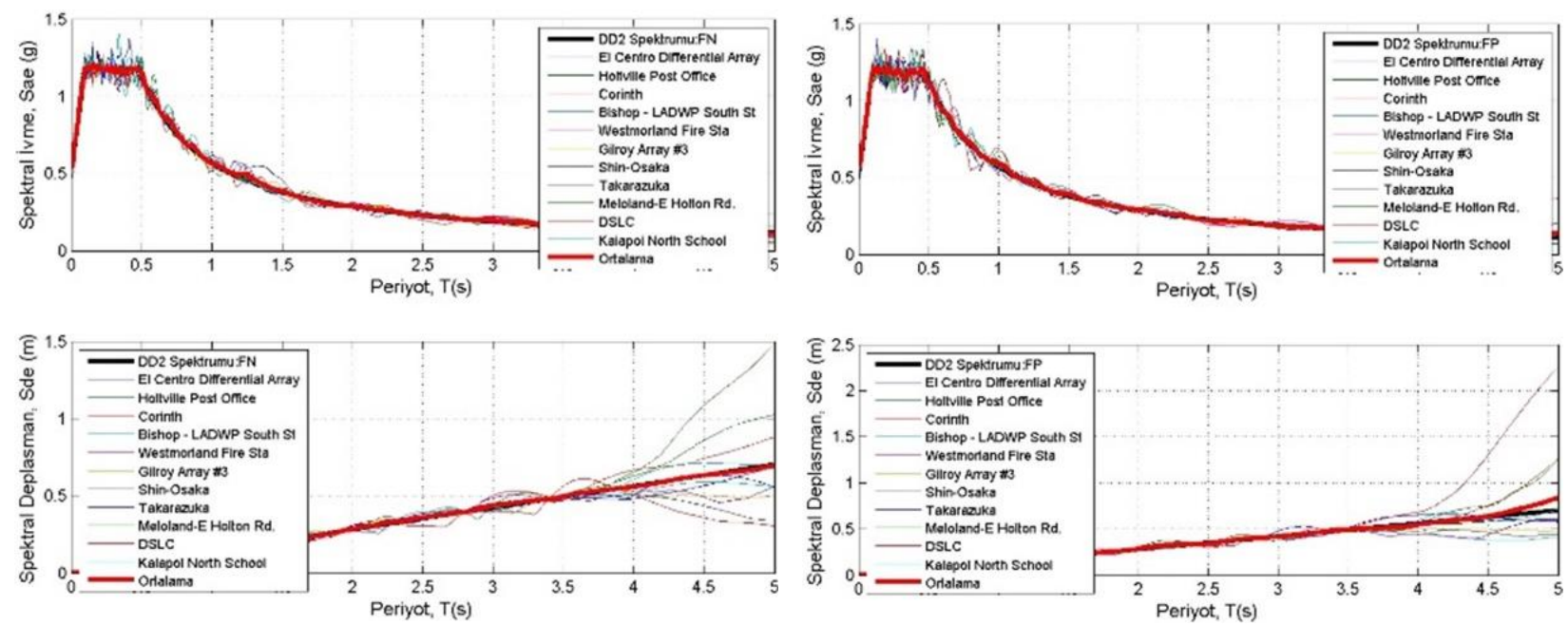

Şekil 9: DD-2 Spektrumu ile uyumlu 11 adet 2 yönlü deprem yer hareketlerinin a) faya normal b) faya paralel doğrultuları için spektral ivme ve spektral deplasman değerleri
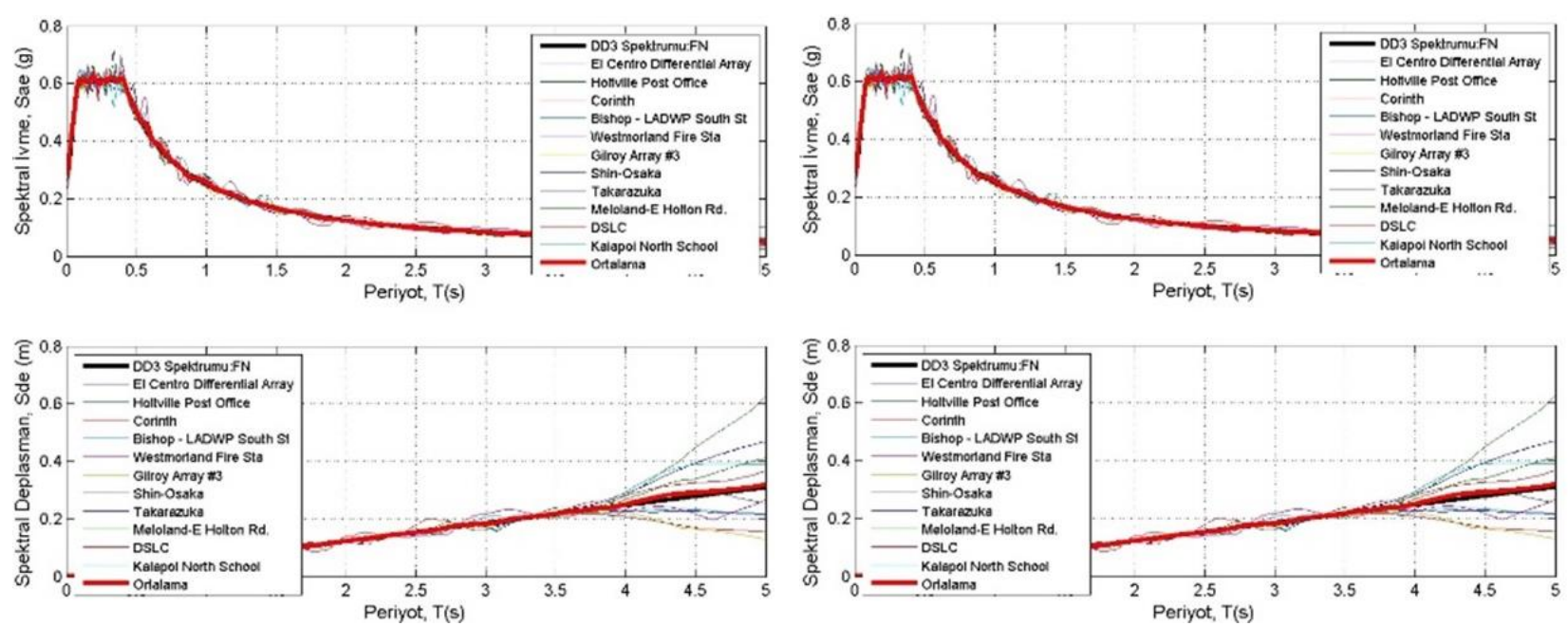

Şekil 10: DD-3 Spektrumu ile uyumlu 11 adet 2 yönlü deprem yer hareketlerinin a) faya normal b) faya paralel doğrultuları için spektral ivme ve spektral deplasman değerleri
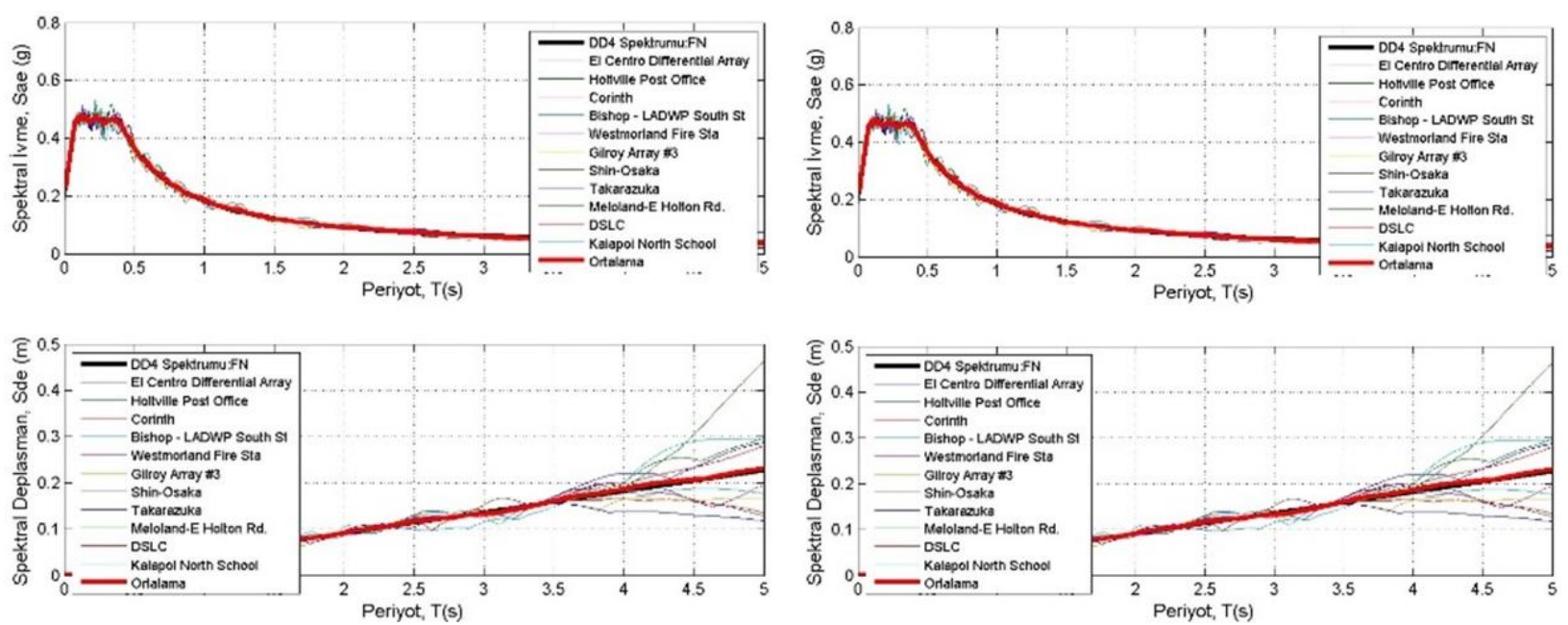

Şekil 11: DD-4 Spektrumu ile uyumlu 11 adet 2 yönlü deprem yer hareketlerinin a) faya normal b) faya paralel doğrultuları için spektral ivme ve spektral deplasman değerleri 
Proje sahası için dört deprem düzeyi için seçilen deprem yer hareketlerinin her iki doğrultudaki spektrumlarının 0.1s-5.0s periyotları arasındaki genlikleri TBDY (2018)'e göre uygun olarak ölçeklendirilmiştir. Ölçeklendirme frekans tanım alanında RspMatch2009 programı kullanılarak yapılmıştır (Spektral uyuşum). RSPMATCH (Al-Atik ve Abrahamson 2010) yazılımı Lilhanand ve Tseng (1987) tarafından zaman tanım aralığı için önerilen yöntem kullanılarak geliştirilmiştir.

\subsection{Zemin Davranış Analizlerinin Yapılması ve Sonuçları}

Sahaya özel zemin davranış analizi çalışması kapsamında 4 deprem düzeyi için elde edilen spektrumlar (Şekil 8, 9, 10, 11) ile uyuşumlu 11 adet deprem yer hareketi kaydının 2 yatay bileşeni (Tablo 5) proje sahası için oluşturulan dört farklı derinlikteki tabakalı zemin modeline (Şekil 3) etkittirilmiştir. Sahaya özel zemin davranış analizleri DeepSoil v7 (Hashash vd. 2020) yazılımı kullanılarak zaman tanım alanında doğrusal olmayan yöntemi (Nonlinear-NL) ile tek boyutlu olarak gerçekleştirilmiştir.

Dört deprem düzeyi ve 30m, 50m, 70m ve 90m derinlik için 11 adet yer hareketi kaydının 2 yatay bileşeni için zemin yüzeyindeki deprem yer hareketi spektrumları, her bir düzey ve derinlik için ayrı ayrı elde edilmiştir. Her iki doğrultu için ayrı ayrı ve daha sonra da bu iki doğrultu sonuçlarının geometrik ortalaması alınarak zemin yüzeyindeki deprem yer hareketi spektrumları elde edilmiş ve ZD zemin sınıfı için elde edilen spektrumla karşılaştırmalı olarak Şekil 9 Şekil 12 ile sunulmuştur.

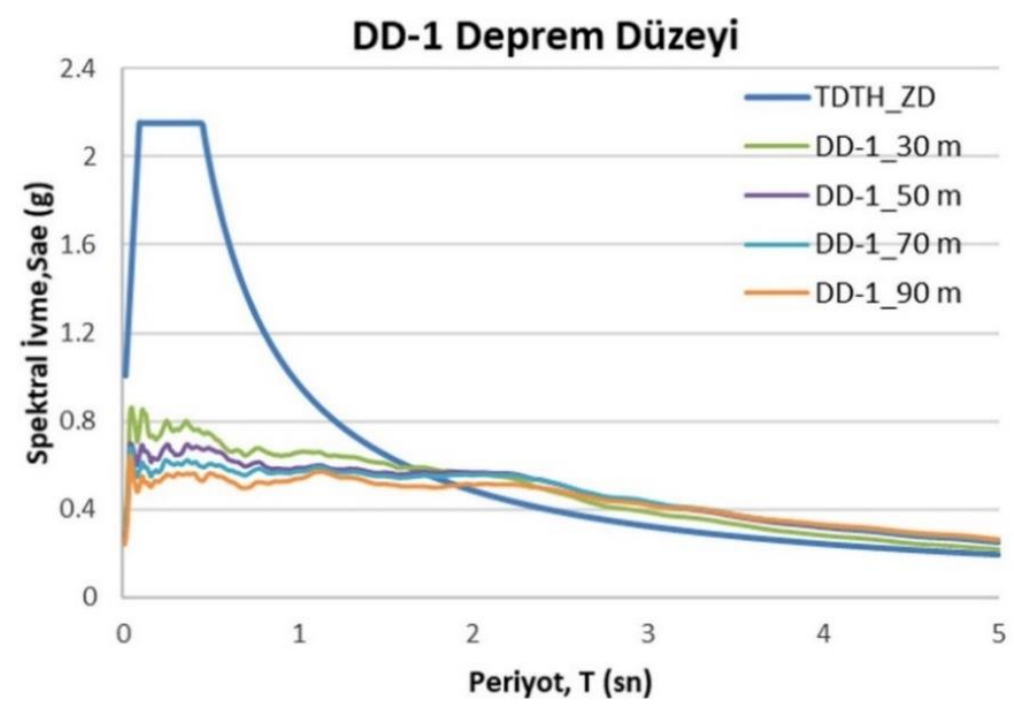

Şekil 12: DD-1 deprem düzeyi için ZDA sonucunda elde edilen zemin yüzeyindeki deprem yer hareketi spektrumları ve TDTH-ZD spektrumunun karşılaştırılması

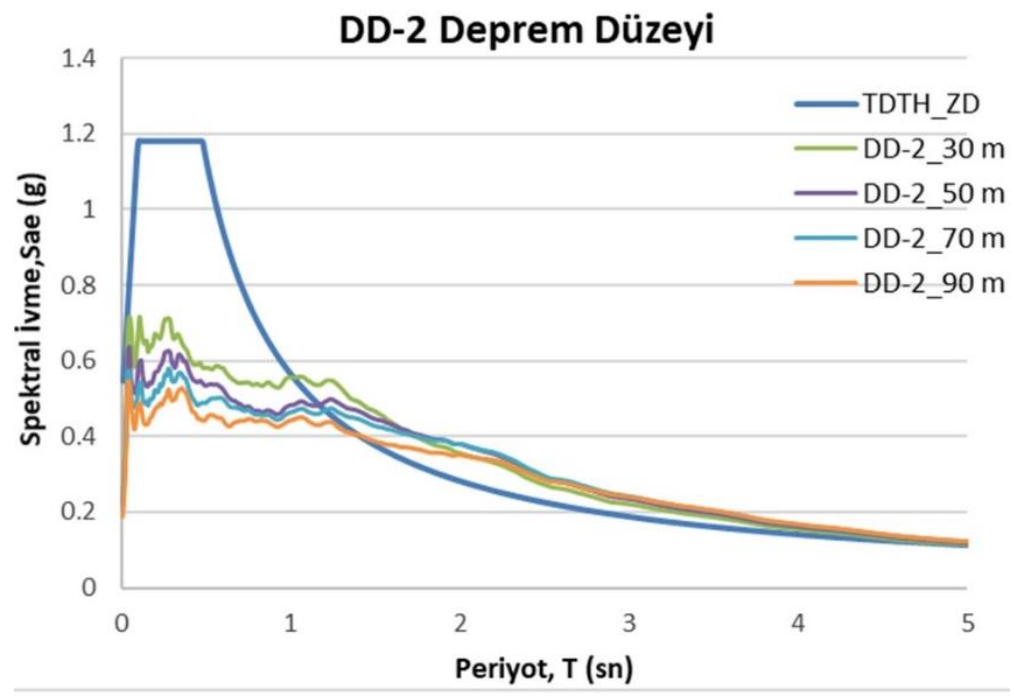

Şekil 13: DD-2 deprem düzeyi için ZDA sonucunda elde edilen zemin yüzeyindeki deprem yer hareketi spektrumları ve TDTH-ZD spektrumunun karşılaştırılması 


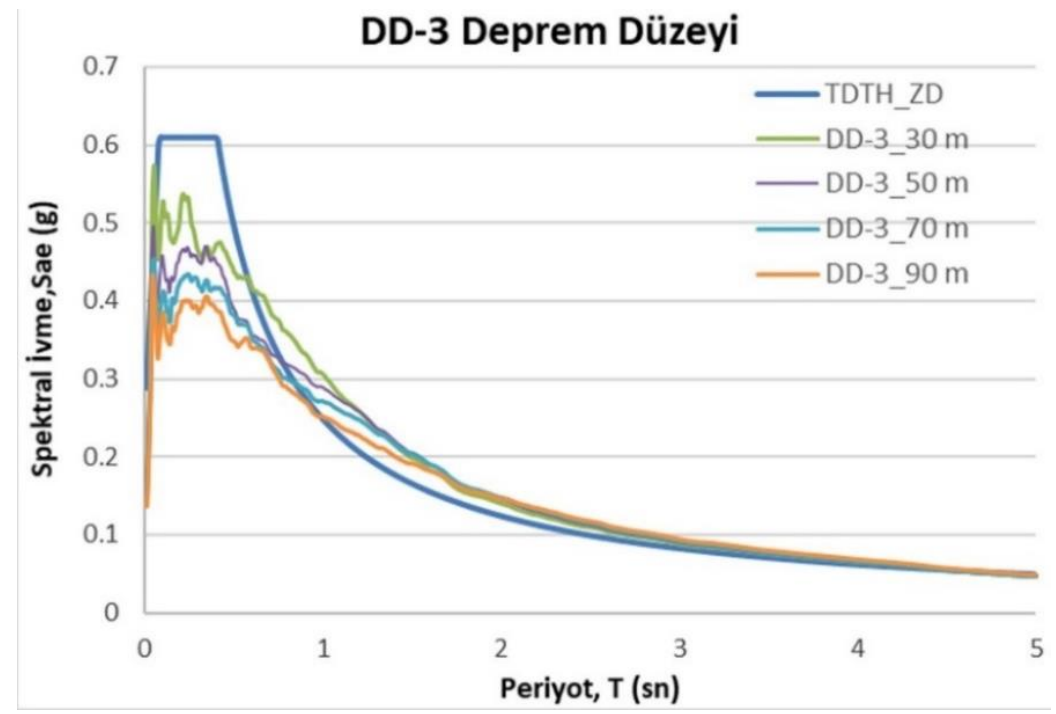

Şekil 14: DD-13 deprem düzeyi için ZDA sonucunda elde edilen zemin yüzeyindeki deprem yer hareketi spektrumları ve TDTH-ZD spektrumunun karşılaştırılması

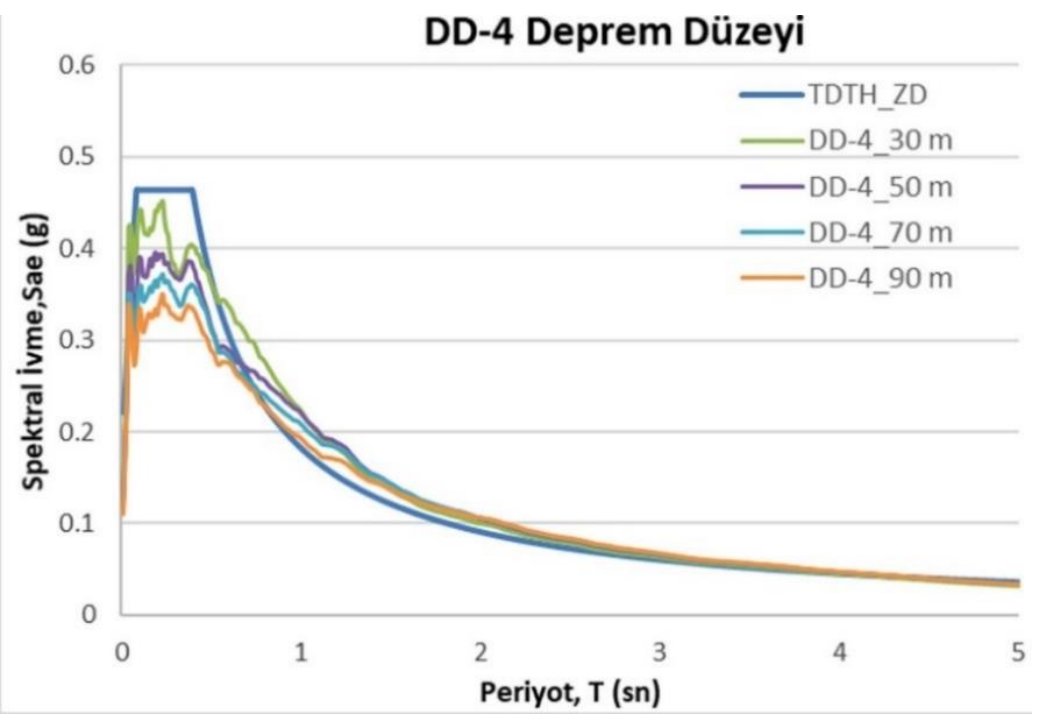

Şekil 15: DD-4 deprem düzeyi için ZDA sonucunda elde edilen zemin yüzeyindeki deprem yer hareketi spektrumları ve TDTH-ZD spektrumunun karşılaştırılması

Şekil 12 Şekil 15 ile sunulan, zemin yüzeyindeki deprem yer hareketi spektrumları ve ZD zemin sınıfı için TBDY-2018 yönetmeliğine göre elde edilen spektrumla karşılaştırıldığında, dört deprem düzeyi ve dört farklı derinlik içinde kısa periyot aralığında yönetmeliğe göre tanımlanan yatay tasarım spektrum değerlerinin zemin davranış analizi sonucu elde edilen spektrumlardan büyük değerler aldığı belirlenmiştir. Özellikle DD-1 ve DD-2 deprem düzeyleri için yönetmeliğe göre tanımlanan spektrumu, analiz sonucu elde edilen spektrumun yaklaşık 2.5-3 katı değerler almaktadır. Orta periyot ve uzun periyot aralıklarında ise zemin davranış sonucu elde edilen spektrumlar yatay tasarım spektrumlarının üzerine çıktığından tasarım spektrumlarının bu bölgelerde davranışı temsil edemediği belirlenmiştir.

TBDY-2018 Madde 16.5.2.5 uyarınca zemin yüzeyindeki sahaya özel deprem spektrumunun belirlenmesi için her bir spektral periyot için zemin yüzeyinde elde edilen on bir kayıtın spektral ivmesinin ortalamasının taban kayası spektral ivmesine oranı hesaplanarak ilgili periyot için yerel zemin etki katsayısı tanımlanmıştır. Bu katsayıların taban kayası spektrumu ile çarpılması sonucunda zemin yüzeyindeki spektral ivme katsayıları elde edilmiştir. Dört deprem seviyesi ve dört derinlik için zemin davranış analizleri sonucu elde edilen zemin yüzeyindeki spektral ivme katsayıları, proje alanının zemin sınıfı ZD ve yönetmelikte en düşük kayma dalga hızı için tanımlanan ZE zemin sınıfı için Türkiye Deprem Tehlike Haritaları İnteraktif Web Uygulamasından alınan spektral ivme katsayıları karşılaştırmalı olarak Tablo 6'te verilmiş̧ir. Spektral değerleri daha iyi değerlendirebilmek ve spektrumları karşılaştırabilmek için zemin davranış analizleri sonucu elde edilen sahaya özel deprem spektrumları ile ZE zemin sınıfı için oluşturulan spektrumun karşılaştırılması Şekil $16,17,18$ ve 19 ile sunulmuştur. 
Tablo 6 ile verilen hem kısa periyot hem de 1.0 sn periyot için elde edilen spektral ivme katsayıları incelendiğinde, zemin davranış analizleri sonucu zemin yüzeyi için elde edilen değerlerin DD-2, DD-3 ve DD-4 deprem düzeyleri için TBDY2018, ZE zemin sınıfı spektral ivme katsayılarının altında kaldığı belirlenmiştir.

Tablo 6: Spektral ivme katsayıları karşılaştırma tablosu

\begin{tabular}{|c|c|c|c|c|c|c|}
\hline & \multicolumn{6}{|c|}{ DD1 } \\
\hline & \multicolumn{3}{|c|}{$\mathrm{S}_{\mathrm{DS}}$} & \multicolumn{3}{|c|}{$\mathrm{S}_{\mathrm{D} 1}$} \\
\hline & ZDA & TDTH-ZL & TDTH-ZE & ZDA & TDTH-ZD & TDTH-ZE \\
\hline $30 \mathrm{~m}$ & 0.854 & \multirow{4}{*}{2.151} & \multirow{4}{*}{1.721} & 1.285 & \multirow{4}{*}{0.964} & \multirow{4}{*}{1.156} \\
\hline $50 \mathrm{~m}$ & 0.693 & & & 1.370 & & \\
\hline $70 \mathrm{~m}$ & 0.619 & & & 1.353 & & \\
\hline $90 \mathrm{~m}$ & 0.559 & & & 1.337 & & \\
\hline
\end{tabular}

\begin{tabular}{|c|c|c|c|c|c|c|}
\hline & \multicolumn{6}{|c|}{ DD2 } \\
\hline & \multicolumn{3}{|c|}{$\mathrm{S}_{\mathrm{DS}}$} & \multicolumn{3}{|c|}{$\mathrm{S}_{\mathrm{D} 1}$} \\
\hline & ZDA & TDTH-ZD & TDTH-ZE & ZDA & TDTH-ZD & TDTH-ZE \\
\hline $30 \mathrm{~m}$ & 0.717 & \multirow{4}{*}{1.181} & \multirow{4}{*}{1.125} & 0.778 & \multirow{4}{*}{0.565} & \multirow{4}{*}{0.806} \\
\hline $50 \mathrm{~m}$ & 0.601 & & & 0.780 & & \\
\hline $70 \mathrm{~m}$ & 0.541 & & & 0.785 & & \\
\hline $90 \mathrm{~m}$ & 0.490 & & & 0.751 & & \\
\hline
\end{tabular}

\begin{tabular}{|c|c|c|c|c|c|c|}
\hline & \multicolumn{6}{|c|}{ DD3 } \\
\hline & \multicolumn{3}{|c|}{$\mathrm{S}_{\mathrm{DS}}$} & \multicolumn{3}{|c|}{$\mathrm{S}_{\mathrm{D} 1}$} \\
\hline & ZDA & TDTH-ZD & TDTH-ZE & ZDA & TDTH-ZD & TDTH-ZE \\
\hline $30 \mathrm{~m}$ & 0.537 & \multirow{4}{*}{0.610} & \multirow{4}{*}{0.805} & 0.310 & \multirow{4}{*}{0.249} & \multirow{4}{*}{0.433} \\
\hline $50 \mathrm{~m}$ & 0.470 & & & 0.314 & & \\
\hline $70 \mathrm{~m}$ & 0.437 & & & 0.307 & & \\
\hline $90 \mathrm{~m}$ & 0.401 & & & 0.294 & & \\
\hline
\end{tabular}

\begin{tabular}{|c|c|c|c|c|c|c|}
\hline & \multicolumn{6}{|c|}{ DD4 } \\
\hline & \multicolumn{3}{|c|}{$\mathrm{S}_{\mathrm{DS}}$} & \multicolumn{3}{|c|}{$\mathrm{S}_{\mathrm{D} 1}$} \\
\hline & ZDA & TDTH-ZD & TDTH-ZE & ZDA & TDTH-ZD & TDTH-ZE \\
\hline $30 \mathrm{~m}$ & 0.452 & \multirow{4}{*}{0.464} & \multirow{4}{*}{0.674} & 0.223 & \multirow{4}{*}{0.182} & \multirow{4}{*}{0.319} \\
\hline $50 \mathrm{~m}$ & 0.396 & & & 0.228 & & \\
\hline $70 \mathrm{~m}$ & 0.372 & & & 0.222 & & \\
\hline $90 \mathrm{~m}$ & 0.350 & & & 0.215 & & \\
\hline
\end{tabular}

Şekil 16,17,18 ve 19 incelendiğinde DD-2, DD-3 ve DD-4 deprem düzeyleri ve ZE zemin sınıfi için deprem yönetmeliği kriterlerine göre oluşturulmuş spektrumun tüm periyot değerlerinde zemin davranış analizi sonucu elde edilen spektrumları güvenli tarafta kalarak kapsadığı belirlenmiştir. DD-1 deprem düzeyi için yönetmelik kriterlerine göre oluşturulan spektrumun orta ve uzun periyot aralığında zemin davranışını temsil etmekte yetersiz kaldığı belirlenmiştir. Ayrıca $30 \mathrm{~m}, 50 \mathrm{~m}, 70 \mathrm{~m}$ ve $90 \mathrm{~m}$ derinlik değişimlerine göre elde dilen spektrumlar incelendiğinde kısa periyot bölgesinde spektrumlar arasında farklılık gözlemlense de özellikle orta ve uzun periyot aralığında bu tür zeminler için analiz sonuçlarını belirgin şekilde etkilemediği belirlenmiştir. Bu durumda genişliği fazla olan bina türü yapı projelerinde mühendislik taban kayasının belirlenmesi için bina temelinden itibaren en büyük bina genişliğinin üç katından ve kazıklı sistemlerde en uzun kazık boyundan daha az olmaması koşulu 30 m'den daha derin sondaj gerektiren proje sahaları için süre ve maliyet giderleri bakımından ek yük getirebilecektir. 


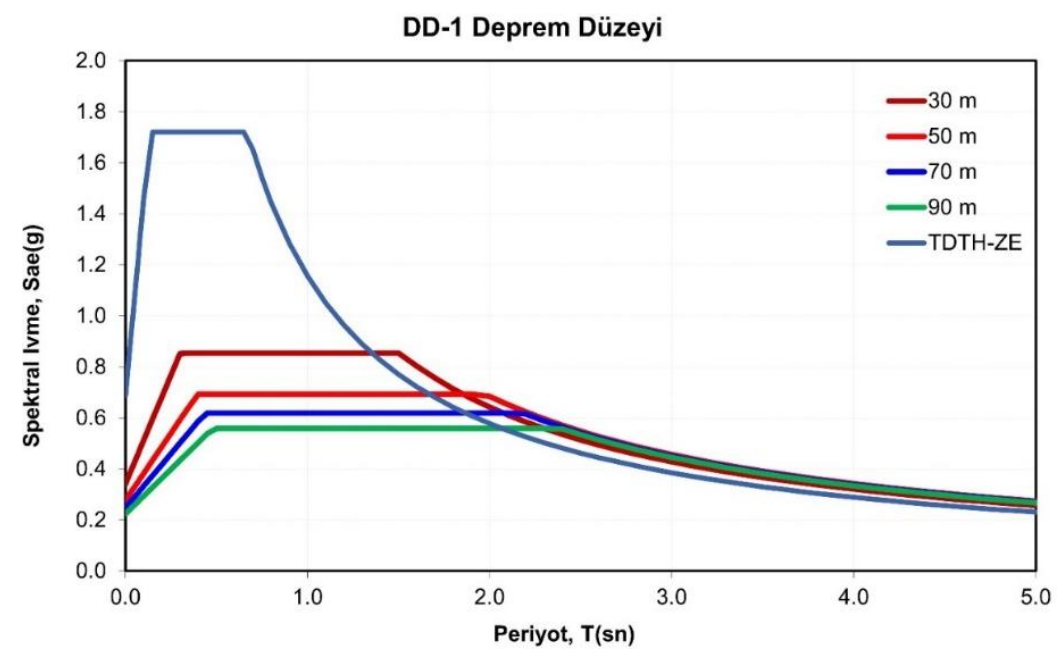

Şekil 16: DD-1 deprem düzeyi için ZDA sonucunda elde edilen zemin yüzeyindeki deprem yer hareketi spektrumları ve TDTH-ZE spektrumunun karşılaştırılması

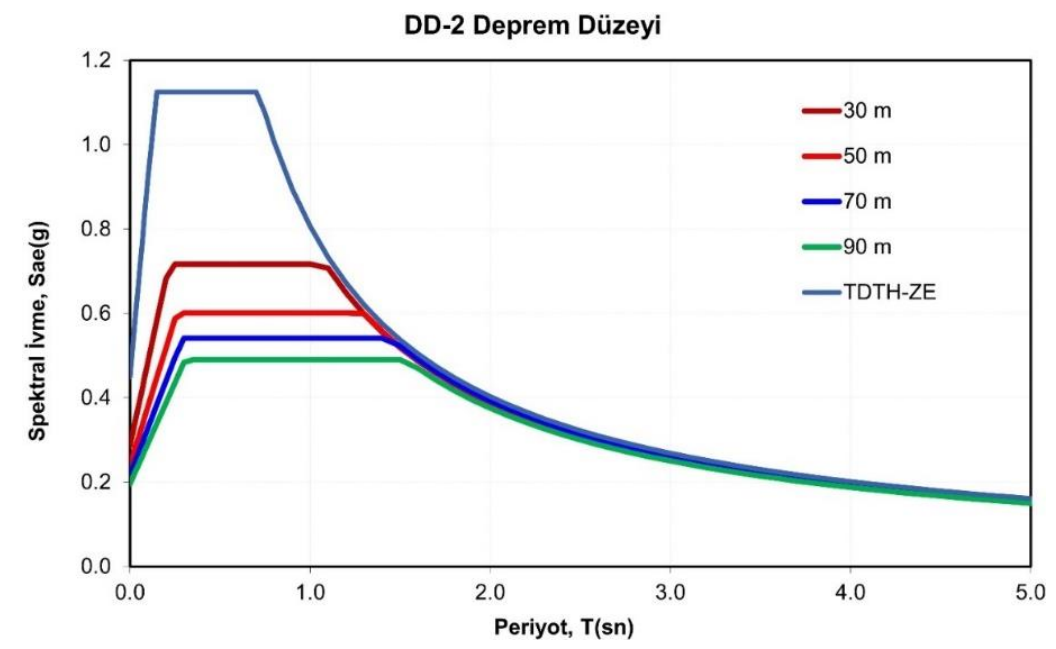

Şekil 17: DD-2 deprem düzeyi için ZDA sonucunda elde edilen zemin yüzeyindeki deprem yer hareketi spektrumları ve TDTH-ZE spektrumunun karşılaştırılması

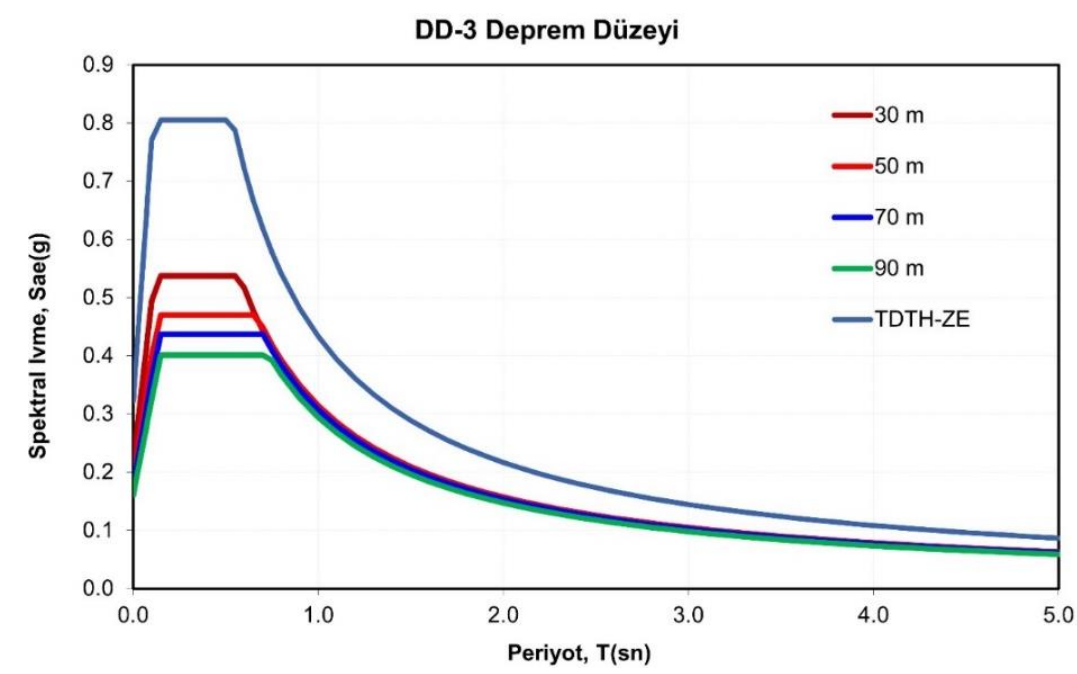

Şekil 18: DD-3 deprem düzeyi için ZDA sonucunda elde edilen zemin yüzeyindeki deprem yer hareketi spektrumları ve TDTH-ZE spektrumunun karşılaştırılması 
DD-4 Deprem Düzeyi

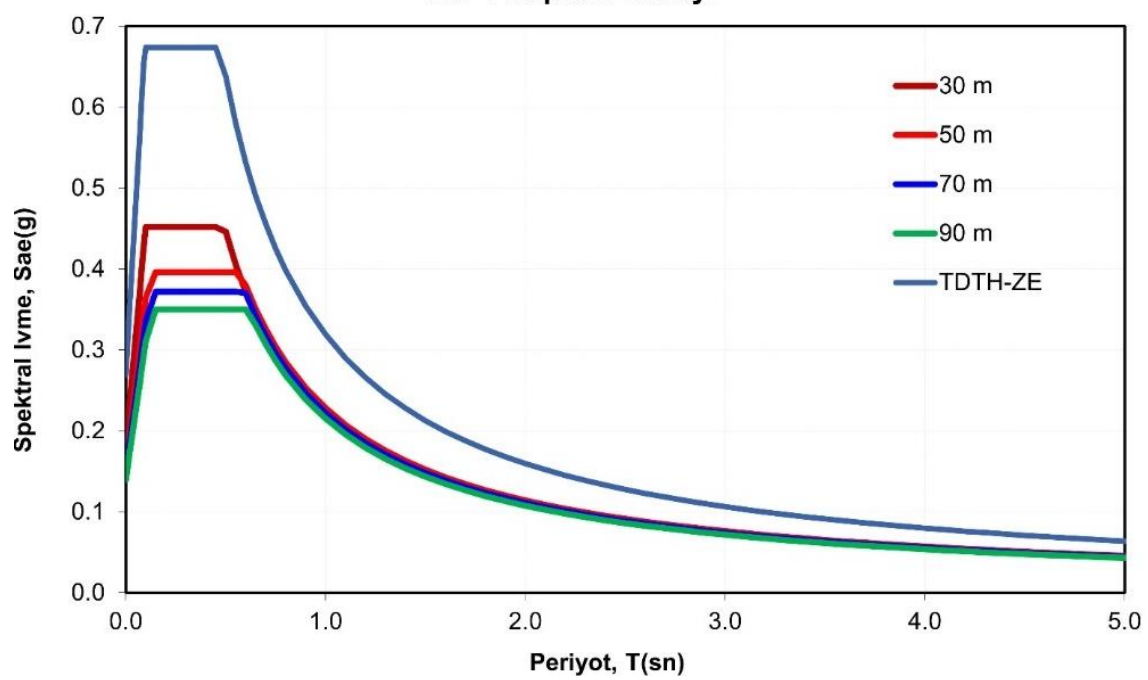

Şekil 19: DD-4 deprem düzeyi için ZDA sonucunda elde edilen zemin yüzeyindeki deprem yer hareketi spektrumları ve TDTH-ZE spektrumunun karşılaştırılması

\section{Sonuçlar ve Öneriler}

$\mathrm{Bu}$ çalışmada, zemin temel etüt çalışmaları kapsamında standart penetrasyon testleri, jeofizik çalışmalar kapsamında sismik kırılma ve çok kanallı yüzey dalgalarının analizi çalışmaları yapılmış ve değerlendirmeler sonucunda TBDY-2018 Tablo 16.1'e göre ZF zemin sınıfı olarak tanımlanmış gerçek bir zemin profili kullanılarak zemin davranış analizleri gerçekleştirilmiştir. Proje sahası olarak İzmir ili, Konak ilçesi sınırlarında bulunan ve bölgenin karakteristik zemin profillini temsil eden bir alan seçilmiştir. Yapılan arazi değerlendirme çalışmalarının sonucunda zemin profillinin kayma dalgası hızının profil boyunca 200 280 m/sn aralığında değiştiği belirlenmiştir. Sismik ölçüm çalışmaları, TBDY-2018 Madde 16.5.2.3 (b) uyarınca $90 \mathrm{~m}$ derinlikte yaklaşık $260 \mathrm{~m} / \mathrm{sn}$ kayma dalgası hızı değeri ile tamamlanmış ve zemin profili ZD zemin tabakası ile sonlandırılmıştır.

TBDY-2018, Madde 16.5.2.3 (a) maddesinde zemin davranış analizleri için serbest zemin modelinin oluşturulması için "mühendislik taban kayasının bina temelinden itibaren derinliğii, en büyük bina genişliğinin üç katından daha az olmayacaktır” koşulunu şart koşmaktadır. Bu koşulun özellikle genişliği fazla olan bina türü yapılar için uygulanması hem pratik olarak zor hem de ek maliyet gerektirmektedir. Profil derinliğinin zemin davranış analiz sonuçlarına etkileri dört farklı deprem düzeyi için incelenmiştir. İnceleme sonucunda standart tasarım deprem yer hareketi "DD-2", sık deprem yer hareketi “DD-3" ve servis deprem yer hareketi "DD-4" için Türkiye Deprem Tehlike Haritaları ve yönetmelik 2.3.3 maddesinde tanımlanan yerel zemin etki katsayıları kullanılarak ZE yerel zemin sınıfı için elde edilen elastik tasarım spektrumlarının davranışı güvenli tarafta kalarak temsil edebildiği belirlenmiştir.

Bu bulgular 1şığında profil boyunca 200 280 m/sn kayma dalgası hızına sahip ve kayma dalgası hızı çok farklılık göstermeyen ancak zemin davranış analizlerini gerektiren zeminler için öneriler aşağıda sunulmuştur;

- Zemin davranış analizlerinin uygulanmasında profil derinliği 30 m'den daha az olmamak üzere TBDY-2018 Madde 16.5.2.3 (a) ile verilen "mühendislik taban kayasının bina temelinden itibaren derinliği, en büyük bina genişliğinin üç katından daha az olmayacaktır” koşuluna özellikle genişliği büyük olan yapılar dikkate alınarak bir üst sinır getirilmesi önerilmektedir.

- İleri performans hedefi değerlendirmesi gerektirmeyen ve yüksek yapı sınıfına girmeyen yeni yapılacak, yerinde dökme betonarme, ön üretimli betonarme ve çelik bina projelerinde "ZE" zemin sınıfi için elde edilen spektrumunun zemin davranış analizi yapılmadan kullanılması önerilmektedir.

- Hâkim periyodu 0.5 sn ve daha küçük olan yapıların tasarımı ve değerlendirilmesinde, zemin davranış analizlerinin yapılmasına gerek olmadan projenin yerel zemin sınıfı için elde edilen spektrumun kullanılması önerilmektedir. Bu koşul Amerikan deprem yönetmeliği ASCE 7-16 (ASCE7-16 2017) Bölüm 20.3.1'de belirtilmektedir.

Gelecekteki Çalışmalar: Farklı zemin sınıfı, profili ve mühendislik kayası tanımları için parametrik olarak oluşturulacak zemin profilleri kullanılarak çalışmanın geliştirilmesi, profil derinliği için bir üst sınır önerilmesi ve hâkim periyodu 0.5 sn ve daha küçük olan yapıların zemin davranış analizlerinden muaf tutulması önerisinin genelleştirilmesi hedeflenmektedir. 


\section{Kaynaklar}

ASCE7-16, (2017), Minimum design loads and associated criteria for buildings and other structures, American Society of Civil Engineers (ASCE), 203ss.

Atik L.A., Abrahamson N., Bommer J.J., Scherbaum F., Cotton F., Kuehn N., (2010), The variability of ground-motion prediction models and its components, Seismological Research letters, 81(5), 794-801.

Başarı E., (2011), Kuzey-Doğu Bursa il merkezi zeminlerinin dinamik zemin davranış analizleri, Dokuz Eylül Üniversitesi, Mühendislik Fakültesi Fen ve Mühendislik Dergisi, 13(1), 39-53.

Bayrakcı S., Baran T., (2018), Zemin dinamik davranışının eşdeğer lineer analiz yöntemi ile belirlenmesi, Osmaniye Korkut Ata Üniversitesi Fen Bilimleri Enstitüsü Dergisi, 1(1), 10-15.

Çağlar N., Kırtel O., Vural İ., Sümer Y., Sarıbıyık A., (2020), 30 Ekim 2020 Mw 6.6 Ege Denizi Seferihisar (İzmir) depremi inceleme ve değerlendirme raporu, Sakarya Uygulamalı Bilimler Üniversitesi, Deprem Çalışmaları Uygulama ve Araştırma Merkezi, Sakarya, 1-27ss.

Ceren K., Karakan E., (2020), Zemin analizleriyle dinamik davranış özelliklerinin belirlenmesine yönelik pilot bir çalışma: Kahramanmaraş ili Üngüt Mahallesi örneği, Doğal Afetler ve Çevre Dergisi, 6(1), 146-156.

Chandler A.M., Lam N.T.K., Sheikh M.N., (2002), Response spectrum predictions for potential near-field and far-field earthquakes affecting Hong Kong: soil sites, Soil Dynamics and Earthquake Engineering, 22(6), 419-440.

DBYBHY, (2007), Deprem Bölgelerinde Yapılacak Binalar Hakkında Yönetmelik, Bayındırlık ve İskan Bakanlığı, T.C. Resmi Gazete, Say1: 26454, Tarih: 6.3.2007, https://www.resmigazete.gov.tr/eskiler/2007/03/20070306-3.htm, [Erişim 28 May1s 2019 ].

Emre Ö., Özalp S., Doğan A., Özaksoy V., Yıldırım C., Göktaş F., (2005), İzmir yakın çevresinin diri fayları ve deprem potansiyelleri, Maden Tetkik ve Arama Genel Müdürlüğü, Jeoloji Etütleri Dairesi, MTA Rapor No: 10754, Ankara.

Emre Ö., Duman T.Y., Özalp S., Elmacı H., Olgun Ş., Şaroğlu F., (2013), Açılamalı Türkiye Diri Fay Haritası. Ölçek 1:1.250.000, Maden Tetkik ve Arama Genel Müdürlüğü, Özel Yayın Serisi-30, Ankara.

Hashash Y.M.A., Musgrove M.I., Harmon J.A., Ilhan O., Xing G., Numanoglu O., Groholski D.R., Phillips C.A., Park D., (2020), DEEPSOIL 7.0, user manual. Urbana, IL, Board of Trustees of University of Illinois at Urbana-Champaign.

Imai T., (1977), $P$ - and $S$-wave velocities of the ground in Japan, Int Conf Soil Mech Found Eng, 9(2), 257-260.

İMO, (2018), Türkiye Bina Deprem Yönetmeliği (TBDY-2018) Eğitim Elkitabı, Açıklamalar ve Uygulama Örnekleri Kısım-I: Genel Konular, TMMOB İnşaat Mühendisleri Odası, Ankara.

Kılıçer S., Özgan K., (2018), Deprem yükü etkisindeki betonarme yapıların tasarımında yapı-zemin etkileşiminin incelenmesi, Doğal Afetler ve Çevre Dergisi, 4(1), 1-10.

Lee S.H.H., (1990), Regression models of shear wave velocities in taipei basin, Journal of the Chinese Institute of Engineers, 13(5), 519-532.

Lilhanand K., Tseng W.S., (1987), Generation of synthetic time histories compatible with multiple-damping design response spectra, In Transactions of the 9th International Conference on Structural Mechanics in Reactor Technology, 17-21 August, Lausanne, Switzerland, Vol. K1, ss. 105-112.

Özmen B., Pampal S., (2017), Türkiye deprem bölgelerï haritalarının evrimi, 4. Uluslararası Deprem Mühendisliği ve Sismoloji Konferans1, 11-13 Ekim, Anadolu Üniversitesi, Eskişehir, Türkiye.

Özmen B., (2012), Türkiye deprem bölgeleri haritalarının tarihsel gelişimi, Türkiye Jeoloji Bülteni, 55(1), 43-55.

Özşahin E., Eroğlu İ., (2018), Erzincan Kentinde Yerel Zemin Özelliklerinin Deprem Duyarlıllğına Etkisi, Doğal Afetler ve Çevre Dergisi, 5(1), 41-57.

PEER Center, (2013), PEER ground motion database, PEER NGA-West2 Database, 3.

Seed H.B., Idriss I.M., (1970), Analyses of ground motions at union bay, seattle during earthquakes and distant nuclear blasts, Bulletin of the Seismological Society of America, 60(1), 125-136.

Sieberg A., (1932), Erdbebengeographie. Band IV, Lieferung 3, Verlag von Gebrüder Borntraeger, Berlin.

Sönmezer Y.B., Akbaş S.O., Işık N.S., (2015), Kırıkkale ili yerleşim alanı için pik ivme, zemin büyütme ve hakim titreşim periyodu özelliklerinin belirlenmesi, Gazi Üniversitesi, Mühendislik Mimarlık Fakültesi Dergisi, 30(4), 711-721.

TBDY, (2018), Türkiye Bina Deprem Yönetmeliği, T.C. Resmî Gazete, Sayı: 30364 (Mükerrer), Tarih: 18.03.2018, https://www.resmigazete.gov.tr/eskiler/2018/03/20180318M1-2.htm, [Erişim 28 Mayıs 2019].

TDTH, (2019), Türkiye Deprem Tehlike Haritaları Interaktif Web Uygulaması, AFAD, https://tdth.afad.gov.tr/TDTH/main.xhtml, [Erişim 28 Mayıs 2019].

Tsang H.H., Chandler A.M., Lam N.T.K., (2006), Estimating non-linear site response by single period approximation, Earthquake Engineering \& Structural Dynamics, 35(9), 1053-1076.

URL-1, (2021), 30 Ekim 2020 Ege Denizi Depremi Basın Bülteni, Boğaziçi Üniversitesi Kandilli Rasathanesi ve Deprem Araştırma Enstitüsü Bölgesel Deprem-Tsunami İzleme ve Değerlendirme Merkezi, http://www.koeri.boun.edu.tr/sismo/2/30-ekim-2020mw6-9-ege-denizi-izmir-depremi/ [Erişim 20 Mayıs 2021].

URL-2, (1999), İzmir Deprem Senaryosu ve Deprem Master Planı, İzmir Büyükşehir Belediyesi, http://www.izmir.bel.tr/izmirdeprem/ index.html [Erişim 28 Mayıs 2019].

URL-3, (2021), Tarihsel Depremler, Boğaziçi Üniversitesi Kandilli Rasathanesi ve Deprem Araştırma Enstitüsü Bölgesel DepremTsunami İzleme ve Değerlendirme Merkezi, http://www.koeri.boun.edu.tr/sismo/2/deprem-bilgileri/tarihsel-depremler/, [Erişim 10 Haziran 2021].

URL-4, (2021), Aletsel Depremler (1900-2021), Boğaziçi Üniversitesi Kandilli Rasathanesi ve Deprem Araştırma Enstitüsü Bölgesel Deprem-Tsunami İzleme ve Değerlendirme Merkezi, http://www.koeri.boun.edu.tr/sismo/zeqdb/, [Erişim 10 Haziran 2021].

USGS, (2020), USGS Vs30 Map Viewer, United States Geological Survey (USGS) https://usgs.maps.arcgis.com/apps/webappviewer/ index.html?id=8ac19bc334f747e486550f32837578e1 [Erişim 02 Haziran 2020].

Vucetic M., Dobry R., (1991), Effect of Soil Plasticity on Cyclic Response, Journal of Geotechnical Engineering, 117(1), 89-107. 